OPEN ACCESS

Edited by:

Carol Kerven,

University College London,

United Kingdom

Reviewed by:

Susanne Vetter,

Rhodes University, South Africa

Dave Daley

California State University, Chico,

United States

*Correspondence:

Lynn Huntsinger

huntsinger@berkeley.edu

Specialty section:

This article was submitted to Agroecology and Ecosystem Services,

a section of the journal

Frontiers in Sustainable Food Systems

Received: 26 May 2021

Accepted: 23 July 2021

Published: 24 August 2021

Citation:

Huntsinger $L$ and Barry S (2021)

Grazing in California's Mediterranean Multi-Firescapes.

Front. Sustain. Food Syst. 5:715366.

doi: 10.3389/fsufs. 2021.715366

\section{Grazing in California's Mediterranean Multi-Firescapes}

\author{
Lynn Huntsinger ${ }^{1 *}$ and Sheila Barry ${ }^{1,2}$ \\ ${ }^{1}$ Environmental Science, Policy, and Management Department, University of California, Berkeley, Berkeley, CA, \\ United States, ${ }^{2}$ Environmental Science, Policy, and Management Department, University of California Cooperative Extension, \\ San Jose, CA, United States
}

The California landscape is layered and multifunctional, both historically and spatially. Currently, wildfire size, frequency, and intensity are without precedent, at great cost to human health, property, and lives. We review the contemporary firescape, the indigenous landscape that shaped pre-contact California's vegetation, the post-contact landscape that led us to our current situation, and the re-imagined grazing-scape that offers potential relief. Vegetation has been profoundly altered by the loss of Indigenous management, introduction of non-native species, implantation of inappropriate, militarized, forest management from western Europe, and climate change, creating novel ecosystems almost always more susceptible to wildfire than before. Vegetation flourishes during the mild wet winters of a Mediterranean climate and dries to a crisp in hot, completely dry, summers. Livestock grazing can break up continuous fuels, reduce rangeland fuels annually, and suppress brush encroachment, yet it is not promoted by federal or state forestry and fire-fighting agencies. Agencies, especially when it comes to fire, operate largely under a command and control model, while ranchers are a diverse group not generally subject to agency regulations, with a culture of autonomy in decisionmaking and a unit of production that is mobile. Concerns about potential loss of control have limited prescribed burning despite landowner and manager enthusiasm. Agriculture and active management in general are much neglected as an approach to developing fire-resistant landscape configurations, yet such interventions are essential. Prescribed burning facilitates grazing; grazing facilitates prescribed burning; both can reduce fuels. Leaving nature "to itself" absent recognizing that California's ecosystems have been irrecoverably altered has become a disaster of enormous proportions. We recommend the development of a database of the effects and uses of prescribed fire and grazing in different vegetation types and regions throughout the state, and suggest linking to existing databases when possible. At present, livestock grazing is California's most widespread vegetation management activity, and if purposefully applied to fuel management has great potential to do more.

Keywords: wildfire, vegetation management, Sierra Nevada, prescribed burning, prescribed grazing, goats, indigenous management

\section{INTRODUCTION: THE LANDSCAPE OF MARS}

On September 9, 2020 we woke up to red skies in our home along the San Francisco Bay. It was more than red skies, actually, the air itself was red (Figure 1). Fires a 100 miles away filled the San Francisco Bay basin with smoke-the common comparison was "waking up on Mars." This was unprecedented in our experience. Some smoke in the air over the Bay used to be an occasional 


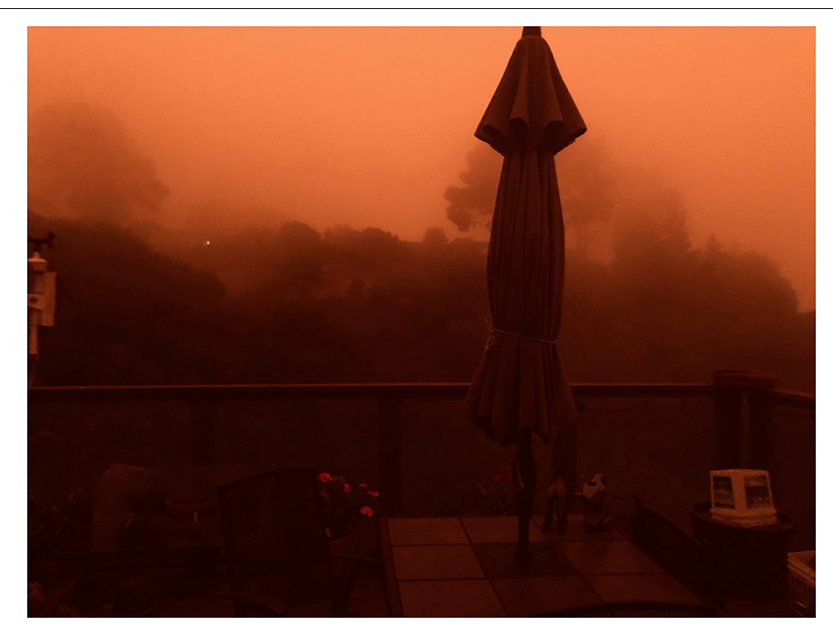

FIGURE 1 | View out the back in El Cerrito, California, September, 2020. Photo: L. Huntsinger.

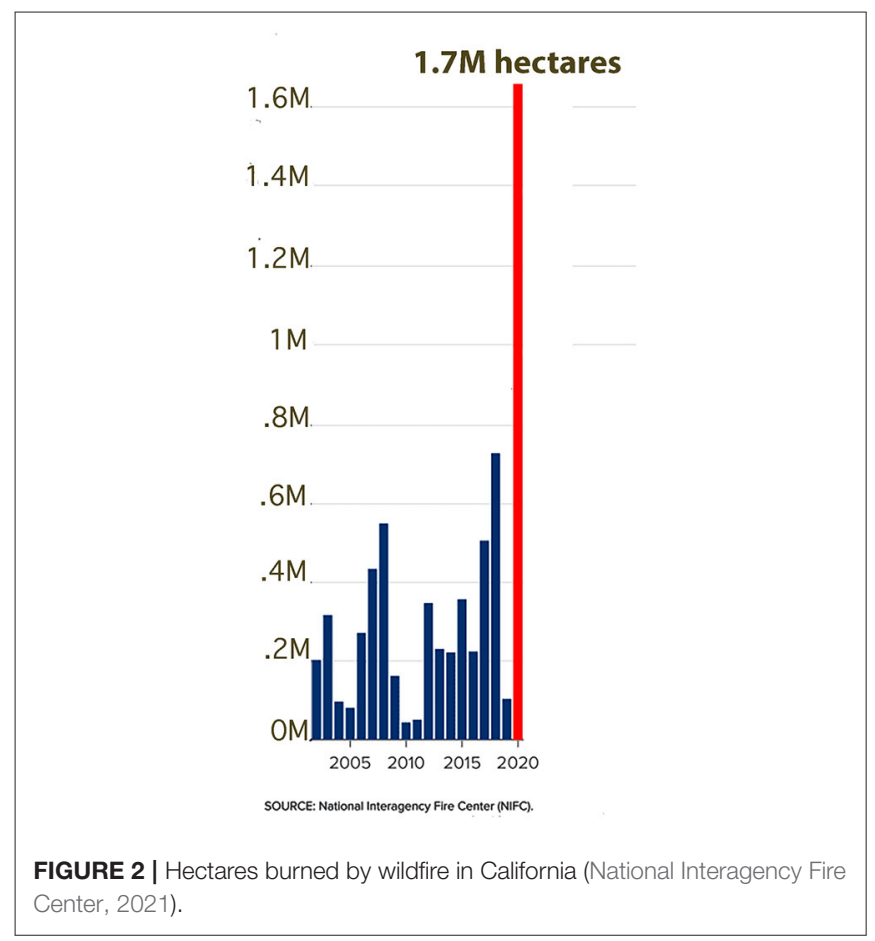

experience, but for the last 10 years California has been pounded with fire after fire. This time it was part of the COVID nightmare of 2020, adding to a year filled with environmental and political dread. More than 1.7 million ha burned that summer and fall, a huge increase over previous years (Figure 2). Suppression of people and fire (Davies et al., 2010, 2015), non-native introductions (Germano et al., 2011; Davies and Nafus, 2013), poor land use planning (Radeloff et al., 2018; Kramer et al., 2019), hands off management, and climate change (Pausas and Fernández-Muñoz, 2011; Abatzoglou and Williams, 2016), are all contributors to the wildfire crisis today.
Vegetation and landscape are influenced by the uses made of them and the values and visions of the societies living with them. California's wildfire crisis is partly a function of society's activities at multiple scales: globally, with the economic and political drivers that feed climate change, nationally, with social attitudes, norms, and values and subsequent policies and practices for land management and conservation, particularly as related to science, fire, and traditional knowledge; statewide, in policies for land use and management; county and municipal level, a locus of land use planning and policy; and locally, with the activities of landowners and residents in fire-prone areas. Ecologically, it is a function of a novel climate interacting with a mix of native and abundant non-native vegetation, and the loss of anthropogenic fire regimes that shaped the vegetation for thousands of years. In the Mediterranean climate regions of the state, mild wet winters that stimulate massive vegetation growth are followed each year by 6-8 months of drought at lower elevations. Nonnative herbaceous annual species provide millions of metric tons of dried, fine fuels starting in late Spring and lasting until deteriorated by Fall rainfall and replaced with new growth. From year to year, rainfall varies by orders of magnitude, and periods of high rainfall causing floods, and droughts lasting more than a year, are not uncommon (Figure 3). This is the perfect set up for regular summer and fall fires.

Livestock grazing in the state converts the non-native annual grasses and forbs on millions of hectares to food and fertilizer, breaking up continuous fuels, removing flammable biomass, and reducing fine fuels that ignite easily and carry fire into woody vegetation. Yet it is startling how few if any of the public agencies in California that manage fire and vegetation, some of the best resourced in the world, mention grazing as a possible fuel management strategy.

The California landscape is layered and multifunctional, both historically and spatially. Managing the firescape is a socialecological endeavor, and needs to be addressed as such in management and research. Here we look at the contemporary firescape, the indigenous landscape that shaped pre-contact California's vegetation, the post contact novel landscape that led to our current situation, and a re-imagined grazing-scape that offers potential relief. Ultimately, we issue a plea: we need to use all possible fuel reduction techniques to create a more fire-resistant landscape. In addition, there are millions of ha of burnt-over lands in California, and how we manage regrowth, particularly in light of the need for climate change adaptation, is critical. Livestock grazing's management of fire fuels will vary based on wide array of social-ecological factors, including vegetation type, land use, location, and governance, and infrastructure. However, introducing or reintroducing grazing to places where it is needed, and developing grazing strategies that are as effective as possible in reducing fire risk, is much needed.

\section{THE CALIFORNIA FIRESCAPE}

The wildfire problem is severe throughout the West and it is becoming more so as climate change warms temperatures 


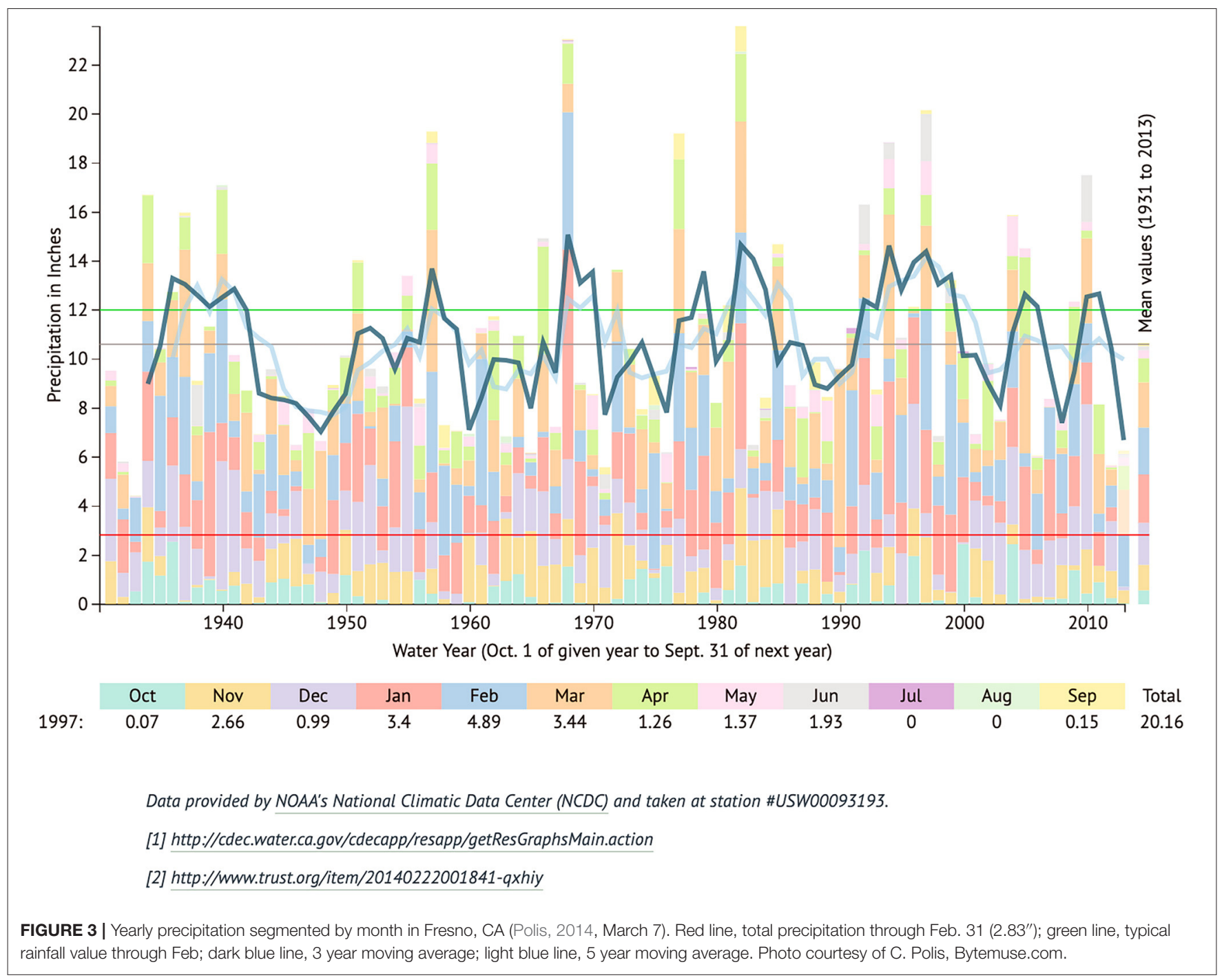

and woody vegetation continues to spread into grasslands, woodlands, and forests (McBride, 1974; Russell and McBride, 2003). California could be called a "perfect storm" when it comes to the wildfire problem: a confluence of climate change and Mediterranean climate weather patterns; massive occupation by high-biomass non-native vegetation; a public that seems increasingly intolerant of active resource management other than protection (Keele and Malmsheimer, 2018); and land use planning that, along with a growing population, has allowed mixing of residential and urban development with natural resource and agricultural land throughout the state (Kocher and Butsic, 2017; Kramer et al., 2019; McBride and Kent, 2019).

Fire suppression has had varied outcomes on plant communities depending on location and vegetation type. For example, in the forests of northern California fire suppression has delayed fire frequencies (Safford and Van de Water, 2014), resulting in millions of dead trees from drought and pests (Goulden and Bales, 2019), and invasion of woody species such as Douglas fir and coyote brush into ungrazed woodlands and grasslands (Lightfoot and Cuthrell, 2015). The resulting fuel characteristics and high fuel loads feed fires of high intensity that are more likely to become crown fires. In the drier southern part of the state, non-native annual plants have invaded formerly sparse shrublands and desert providing fine fuels that carry fire across the landscape. Shrubland areas in the warmer and drier southland are now burning more frequently than under presettlement conditions, and coupled with site occupation by annual invasives, in some vulnerable shrub types, conversion from shrubland to grassland has resulted (Safford and Van de Water, 2014; Allen et al., 2019). Keeley posits that fires in forest ecosystems are driven largely by accumulations of dry fuels, while those in coastal grasslands are in large part driven by winds, though these two factors and many others also have an influence in both types (Keeley and Syphard, 2019). Archibald defines 5 different syndromes of fire regimes, or pyromes, globally based on human impacts and distinctions between crown, litter, and grass-fueled fires (Archibald et al., 2013). 


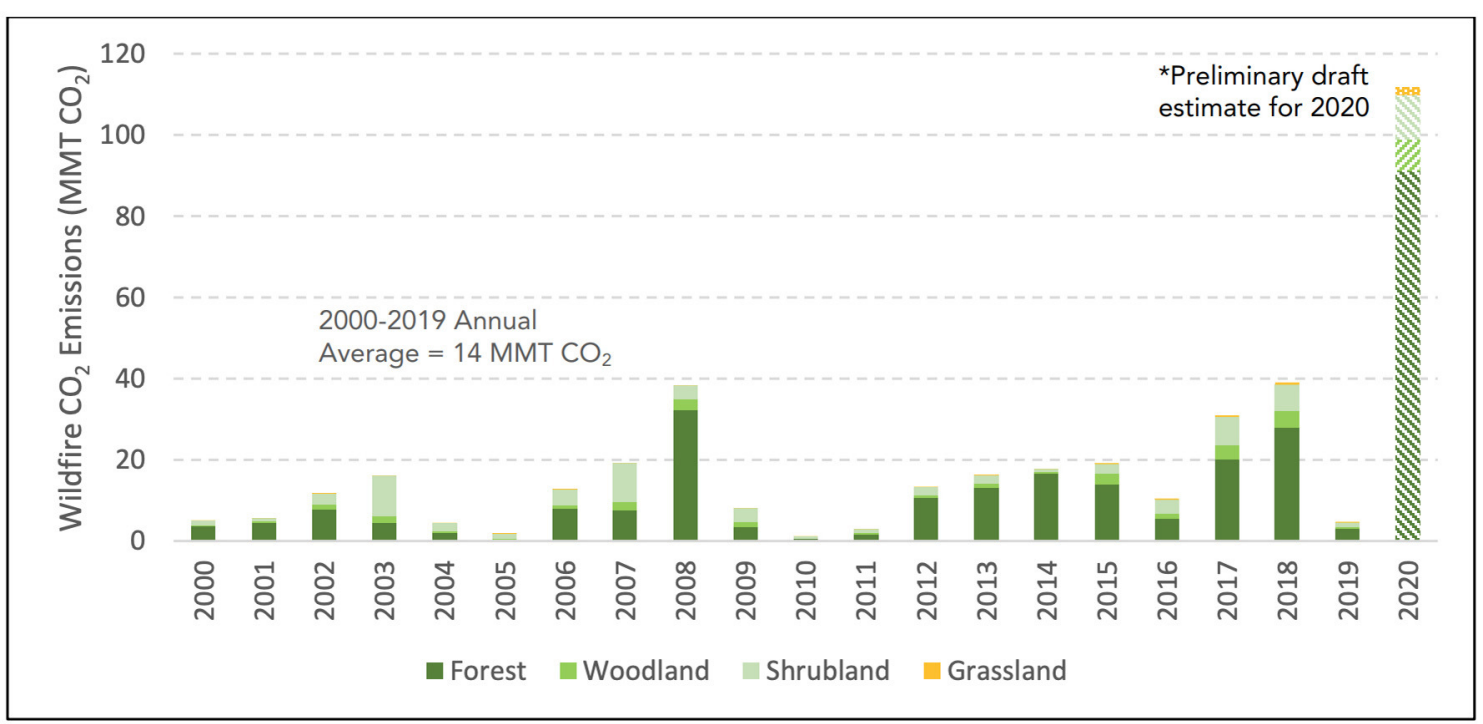

*Preliminary draft estimate of 2020 wildfire emissions will be updated and revised when CAL FIRE's final fire perimeters become available in mid-2021.

FIGURE 4 | Annual wildfire emissions in California (California Air Resources Board, 2020).

Overall, the state faces deadly wildfires of increasing size, frequency, and intensity, and growing in costs (Figure 2). The collateral damage is serious and affects all Californians: smoke threatens human health in the cities as well as near the wildlands (Koman et al., 2019; Liang et al., 2021); carbon emissions and loss of carbon stock contribute to climate change (North and Hurteau, 2011), and costs add to the public ledger (Diaz, 2012; Kousky et al., 2018). For those directly affected by fires, lives and homes are lost, businesses are destroyed, the landscape of home is profoundly changed (Waks et al., 2019). Life is disrupted in terrible ways.

\section{A Deadly and Costly Landscape}

Wildfires contribute to climate change by emitting carbon dioxide and black carbon into the atmosphere. According to preliminary figures provided by the California Air Resources Board, in 2020 California wildfires emitted 111.7 million metric tons of carbon dioxide, compared with an estimated 180 million metric tons of carbon dioxide equivalent for transportation in 2018, the most recent year for which greenhouse gas figures are available by sector (Figure 4). Globally, from 1997 to 2001, average annual carbon emissions from landscape fires, including wild and prescribed forest fires, tropical deforestation fires, peat fires, agricultural burning, and grass fires, was $\sim 2$ petagrams $\left(2 \times 10^{12} \mathrm{~kg}\right)$ (van der Werf et al., 2010). These emissions affect planetary processes such as radiative forcing, which influences average global temperature, and hydrological cycles, which influence regional cloud formation and rainfall (Yokelson et al., 2007; Cochrane and Laurance, 2008; Fargione et al., 2008; Bowman et al., 2009; Langmann et al., 2009; Tosca et al., 2010). Extensive and intense wildfires in the Pacific Northwest in 2017 injected large quantities into the stratosphere. Solar heating of black carbon caused smoke to rise 12-23 kilometers above within 2 months, where it remained in the stratosphere for more than 8 months (Yu et al., 2019).

Californians from all walks of life, in rural areas and large cities, are being exposed to smoke each summer. The most important risk-related measure of smoke is particulate matter $(\mathrm{PM})$ with an aerodynamic diameter $\leq 2.5 \mu \mathrm{m}\left(\mathrm{PM}_{2.5}\right)$. Wildfire smoke particles impact respiratory health more than fine particles from other sources (Aguilera et al., 2021). Smoke from the combustion of vegetation and buildings is composed of hundreds of chemicals, many of which are known to be harmful to human health (Naeher et al., 2007). In late August and early September of 2020, with hundreds of wildfires occurring simultaneously in the state, Air Quality Index (AQI) data reported by the U.S. Environmental Protection Agency for ozone and PM2.5 in many California counties was often far beyond unhealthy in the later part of August and early September (Burke, 2020).

The massive amounts of smoke released by wildfires is believed not only to cause lung problems (Bassein et al., 2019), but to suppress immune systems-there is evidence from animal studies that the immune suppressive effects may persist for as long as 12 years after exposure (Miller et al., 2020). Air pollution from fires puts exposed children at greater risk of disease in adulthood (Prunicki et al., 2021). Globally, around 339,000 annual deaths were attributed to exposure to landscape fire smoke in a 2012 study (Johnston et al., 2012). Asthma and chronic obstructive pulmonary disease (COPD), were consistently associated with wildfire smoke exposure (Reid et al., 2016). Other potential effects include cardiovascular and mental health (Haikerwal et al., 2015; Wettstein et al., 2018; 


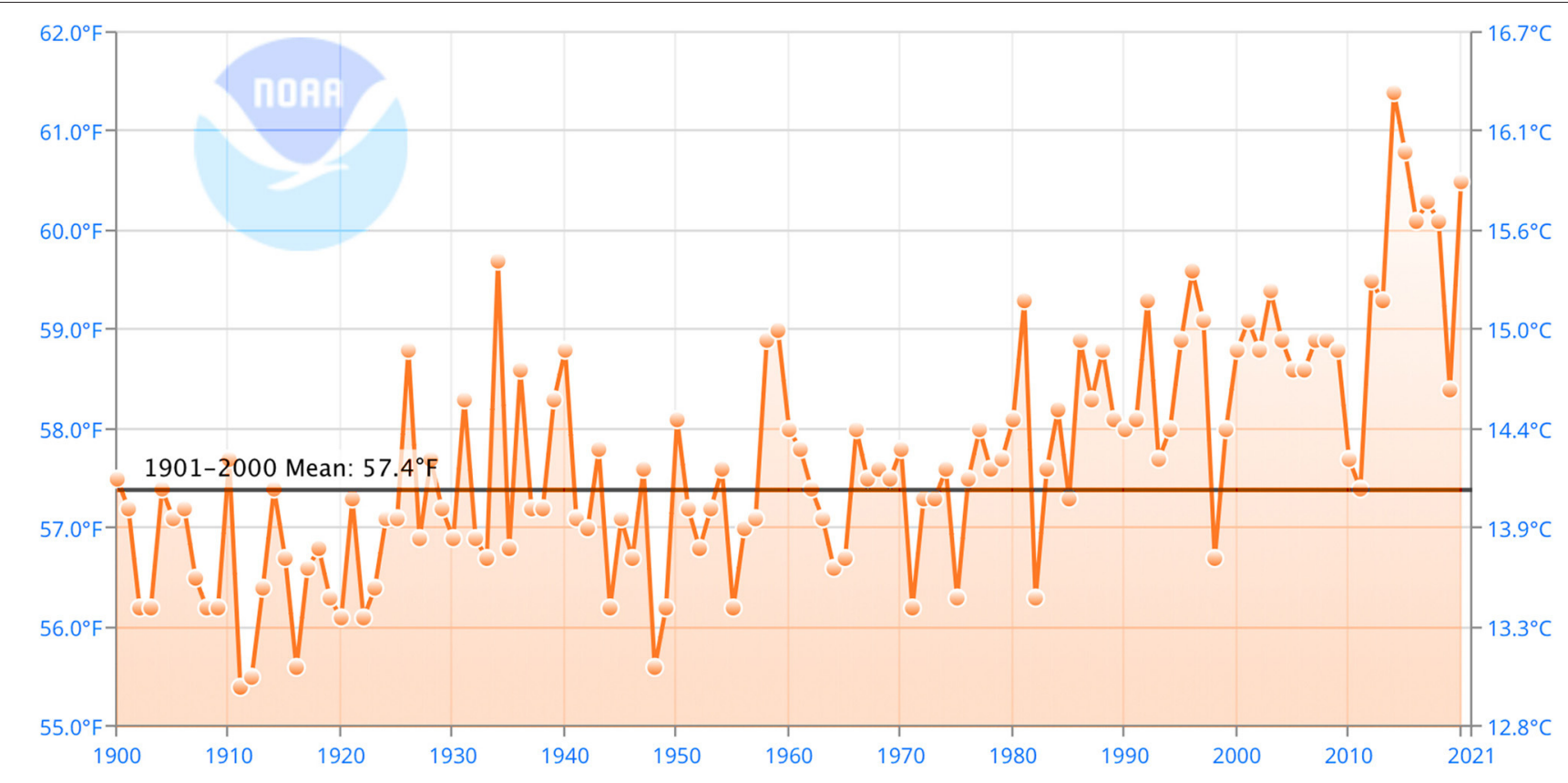

FIGURE 5 | California average annual temperatures, Jan-Dec, 1900-2020 (National Oceanic and Atmospheric Administration, 2021).

Zhang et al., 2018), though inconsistency in findings remains (Moore et al., 2006; DeFlorio-Barker et al., 2019). New research attributes a skin disease to smoke (Fadadu et al., 2021). Common estimates are that thousands of mortalities in California can be related to smoke exposure over the last few years (Burke, 2020).

Costs also come in cold hard cash. California's 2018 wildfires cost the US economy $\$ 148.5 \mathrm{bn}, 0.7 \%$ of the country's annual GDP, of which $\$ 45.9 \mathrm{bn}$ was lost outside the state (Wang et al., 2021). The state itself incurred damages of $\$ 102.6 \mathrm{bn}$, roughly $0.5 \%$ of the US's annual GDP. While capital losses and health costs within California totaled $\$ 59.9 \mathrm{bn}$, indirect losses through economic disruption to 80 industry sectors within the state came to $\$ 42.7 \mathrm{bn}$. Productivities were reduced due to illness brought on by fires. The slowdown in production caused ripple effects to economic supply chains within California as in 49 other states, and internationally (Wang et al., 2021). These costs affect all California residents, through taxes, prices, job opportunities, and health costs.

Aside from the Mediterranean climate, and growing populations of people living in homes intermixed with flammable forest and rangelands, there are two lines of thought about the major driver of this current crisis. One is that the main driver is ongoing climate change and its attendant warming, and the other is that the driver is a lack of adequate vegetation management and a history of forest and rangeland use that has left us with an overabundance of flammable vegetation on the land. Both are important, and they are inter-related.

\section{Climate Change and the Firescape}

Temperatures in California are warming, exacerbating the influence of drought and changing habitat conditions for animals

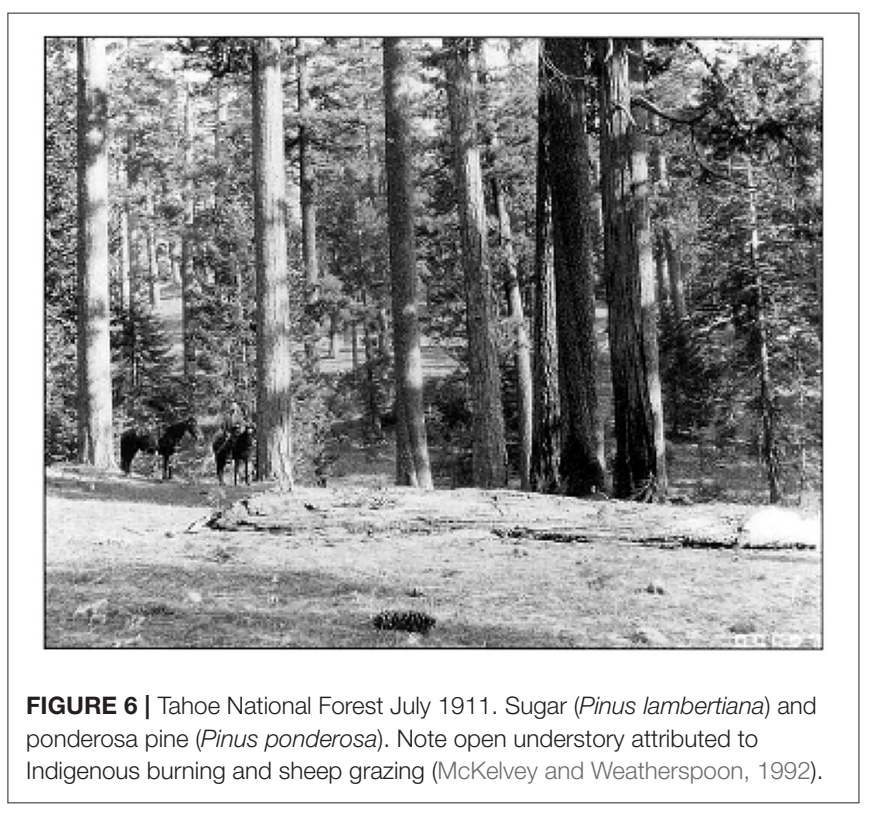

and plants (Figure 5). From 2010 to 2018, nearly 150 million conifers have died of drought and disease in the central Sierra Nevada, at the end of one of the driest series of years on record (Axelson et al., 2019; Larvie et al., 2019). This is a factor in California, but also around the world. In 2017, fires in Portugal took more than 120 lives, in infernos that covered 500,000 hectares (Turco et al., 2019). In 2018, the deadliest fire season in Greek history killed over 100 people (Paphitis and Gatopoulos, 
2019), and in California, the Camp Fire left 88 people dead and damaged over 18,000 structures (Syifa et al., 2020). Australia's fire-prone savanna and forest caught fire ferociously throughout the country in 2019 during the dry season, the hottest climate year ever (Richards et al., 2020), releasing 337 million tons of $\mathrm{CO}^{2}$ (Global Fire Data, 2021). Even northern Europe is experiencing a growing fire problem. In 2018 there were more than 50 wildfires in Sweden, including some in the Arctic Circle, and researchers have argued that because of wildfire, plantation forests overall act as a source rather than sink for $\mathrm{CO}^{2}$ (Naudts et al., 2016).

Studies show that not only is annual mean temperature increasing, but also the seasonal mean temperature and maximum and minimum temperature of seasons are increasing in California (Pathak et al., 2018). These increments in seasonal mean temperature affect the ecosystem differently. Increasing temperatures in winter and spring are generally considered to expedite snowpack melting earlier in the spring and reduce the total amount of snowpack (Westerling and Bryant, 2007). Higher temperatures in summer and fall are usually associated with prolonged drought and higher risk of extreme wildfires. The Sierra Nevada snowpack acts as a reservoir that supplies water to California's vast croplands and cities in the dry season and maintains the health of montane meadows and diverse ecosystems. Because of the rise in temperature, the total volume of snowpack has decreased by 40-90\% (Godsey et al., 2013). Higher temperatures and less snowpack have supported forest expansion at higher elevations (Taylor, 1995).

\section{CALIFORNIA'S INDIGENOUS FIRESCAPE}

The indigenous firescape was forged by the frequent burning of the state's indigenous people, who arrived at least 12,000 years ago (Lightfoot and Cuthrell, 2015). At the time of contact fire was the major tool Native Americans used for managing the environment they depended on. John Muir's "range of light" (Muir, 1911, p. 316), was a Sierra Nevada of "floods of light" (Muir, 1911, p. 170) with open forests where you could see for miles between the trees. This was a creation of indigenous stewardship (Figure 6). Muir took it to be a wilderness, and while sensitive to the effects of geology, he seemingly was blind to the landscape engineering of Native Americans, an oversight that unfortunately became an underpinning of the preservationist movement he helped found. Protecting and leaving ecosystems alone would preserve "God's wildness," wherein was "the hope of the world-the great fresh, unblighted, unredeemed wilderness" (Muir, 1979, p. 317). In seeking this imagined wilderness, the creation of a European sensibility and culture that suited the transcendental commitment to the unique values of America, changed ecosystems were created that are now prone to high intensity, seemingly ever-larger and more destructive, wildfires.

California's forest and rangeland management is intertwined with a story of colonial violence, human and cultural suppression, and the focus in this paper, misguided introductions of management paradigms from the more mesic parts of Europe. Estimates of the pre-contact number of indigenous peoples in California are over 300,000 (Cook, 1976), with some estimates much higher (Powers, 1872). Regular burning attracted game and created open grasslands and woodlands where indigenous foods, including acorns and grassland seeds, were abundant. Fire kept less useful conifers at bay (Evett and Cuthrell, 2013). Burning took place often, sometimes annually, and for this reason had not so much fuel to consume, leading to low intensity fires that left few tree scars behind and were limited in extent (Powell, 1890 in Blackburn and Anderson, 1993; Huntsinger and McCaffrey, 1995; DeBuys, 2001; Keeley, 2002; Anderson, 2013). Such fires were reported by early explorers, and described in the accounts of California's indigenous people along with a rich lore on the use of fire for manipulating vegetation. Heady and Zinke (1978) suggest that indigenous people were a major factor in preventing tree regeneration during pre-settlement times.

California's native peoples were much abused by a succession of colonizations by Spain, Mexico, and the United States after 1769. The Spanish rounded them up and forced them to live and work in the missions, Mexico disenfranchised them of the Mission lands they were supposed to inherit, and California enslaved and outright sought to exterminate them. In 1851, Peter Burnett, the state's governor, said that "a war of extermination will continue to be waged between the races, until the Indian race becomes extinct, must be expected. While we cannot anticipate this result but with painful regret, the inevitable destiny of the race is beyond the power or wisdom of man to avert" (Burnett, 1852, p. 15). Close to a million dollars were spent between 1850 and 1852 on "expeditions against the Indians" (Comptroller of the State of California, 1859). Following that, with further attempts to stamp out native culture in the twentieth century, it is no surprise that indigenous long-term knowledge of ecology was not used in developing policies for forest and land management in California. Even the anthropologists who studied California's indigenous people paid scant attention to the use and management of the environment-the prevailing attitude was that they simply lived off nature, rather than actively managing for production of needed materials (Anderson, 2013). This idea contributed to the concept of North America as wilderness and the general discounting by ecologists of former management, and lent justification to the dispossession of native lands (Cronon, 1983). Yet with the technology of fire, Native Californians had a great influence on the California landscape. In interviews, indigenous respondents along the Klamath said, for example, "we burned every year after hunting as we came down out of the forest" (Huntsinger and McCaffrey, 1995).

\section{Early Colonial Impacts on California's Indigenous Firescape}

Spanish colonization and other early colonial forays into California left another legacy that began the huge ecological changes that continue today. Inadvertent and purposeful introduction of alien seed into the state in the eighteenth and nineteenth centuries is an ongoing globalization process. The flora has changed, most notably, with a takeover of native grass and forb lands by large-statured annual grasses, pre-adapted to cultivation and grazing, that are able to take maximum advantage of whatever rainfall comes. An annual class experiment in 
the UC Berkeley greenhouses consistently finds that under identical growing conditions, wild oats (Avena fatua), a typical ubiquitous non-native grass in California, is taller, and has much greater above and below ground biomass, than a typical native bunchgrass, purple needlegrass (Stipa pulchra), after 20 weeks of growth (pers comm. Huntsinger). The non-native grasses produce abundant, highly fecund seed and create a rich, long lasting seedbank; purple needlegrass seed is not as abundant or as likely to germinate (Jackson, 1985). New plants, broadleaves and grasses, continue to arrive, and cannot be eradicated. The subsequent novel ecosystem is highly fire prone (Seastedt et al., 2008; Hobbs et al., 2014). Not only do the non-native grasses grow bigger and faster with sufficient rainfall, and crowd and overshadow native species, they are continuous fuels, without gaps between plants, and they die and dry completely in the summer. They choke out habitat for numerous species that evolved without them (Barry and Huntsinger, 2021).

The Spanish introduced livestock grazing to California when they arrived in 1769. Livestock grazing gradually evolved from a "frontier" style of letting animals graze and rounding them up once in a while to more controlled ranch grazing, which grew more established through the nineteenth and early twentieth century (Burcham, 1982). The Gold Rush of 1849 brought graziers into the mountains, creating a system of transhumance from grasslands and oak woodlands to forests and montane meadows (Huntsinger et al., 2010). Private properties in California's lowlands could be quite large, based on Spanish and Mexican land grants that survived statehood, but as the nineteenth century came to a close, the federal government and the state asserted ownership of much of the higher elevation public domain forests, and eventually the deserts, both lands whose physical characteristics limited homesteading. The federal government owns at least $47 \%$ percent of California's total area, 19 million ha out of 40 million total (California Department of Forestry and Fire Protection, 2010).

\section{THE TWENTIETH CENTURY FIRESCAPE}

The twentieth century California firescape was one of thickening woody vegetation in much of the state, relentless herbaceous annual production and spread, and increased human occupancy and development in forests and rangelands. Concerns about erosion and loss of watersheds due to grazing, burning, mining, and illicit timber harvesting led to the setting aside of forest reserves in the Forest Reserve Act of 1891, followed by the 1897 Organic Act that initiated the administration and protection of the reserves as a Forest Reserve System. The Federal Forest Transfer Act of 1905, signed into law by President Theodore Roosevelt, moved control of the forest reserves from Interior to the USDA's Bureau of Forestry, soon renamed the Forest Service, overseeing what would now be called the national forests. The first Chief of the Forest Service and former head of the Division of Forestry was Gifford Pinchot. Pinchot's forest management was shaped by the mentorship of Bernhard Fernow, Chief of the Division of Forestry before Pinchot and formerly a member of the Prussian Forest Service. In general, American foresters took their models for forest management from abroad, including Britain's colonial practices in India. Pinchot studied forestry in western Europe, where he attended L'Ecole Nationale Forestière, the elite French forestry school in Nancy (Barton, 2000). Fernow was from an aristocratic Prussian family, trained in Prussian silviculture. Pinchot became a strong promoter of profitable, scientific forestry that provided the "greatest good for the greatest number" by relying on scientific methods (Miller, 2001, p. 330). The early twentieth century was one of much celebrated scientific discovery, and along with that the creation of some of our major land management institutions. Pinchot developed professional forest management in the United States, which included a foundational belief that forestry was solely a biological undertaking, based in objective science and immune to the influence of non-biologists (Fairfax and Fortmann, 1990). This fit well with the growing fascination with inventions and science in the early twentieth century.

Forests were promoted as a military and economic good in the Europe of the eighteenth and nineteenth centuries-it took 2000 two-ton oaks to make a British warship (Schama, 1995, p. 173)and given the frequency of wars and needs for transport, trees were precious and managed intensively. From the first British laws preserving tall timbers in the colonies for ship masts, the management of forests took on a military ambiance. Forests had connections to royalty, with forests set aside as hunting reserves for the King and aristocracy. Growing trees in England became an aristocratic pursuit as their value for the military and national security increased (Schama, 1995). The belief that trees were rare, in need of intensive management, and of high value to society was a politically powerful and somewhat inappropriate ideology used to promote the development of the U.S. Forest Service in a country with vast numbers of trees and a relatively small population (Behan, 1975). In fact, harking back to the military significance of European forests, and reflecting distrust of self-interested local populations, federal and state foresters in California wear paramilitary uniforms. Muir himself commented that "one soldier in the woods, armed with authority and a gun, would be more effective in forest preservation than millions of forbidding notices" for keeping sheepherders out of the Sierra (Bowers et al., 1895). Often Basque, Irish, Italian, or Mexican, sheepherders were lamented as immigrants who did not care for the land, letting their bands of sheep overgraze and damage soils and vegetation. President Theodore Roosevelt wrote the following in 1895:

\footnotetext{
Many of the people in these imperiled legions are not permanent inhabitants at all; they are mere nomads, with no intention of remaining for any great length of time in the locality where they happen to be for the moment, and with still less idea of seeing their children grow up there. They, of course, care nothing whatever for the future of the country; they destroy the trees and render the land barren... The damage from deforestation is often very severely felt in land remote from the deforested region. Because of this fact alone the whole matter should be in the hands of the National Government...and West Point would seem to be the proper place in which to establish the chair of instruction [in forestry] (Bowers et al., 1895).
} 
Basque sheepherders were characterized "as a group of landless and marginal peasants whose activities were detrimental to the public interest" in the words of a prominent financier in Elko, Nevada in 1909 (Saitua, 2019). Yet in fact, under the Constitution sheepherders had as much right to use the public domain as anyone else.

From Native American homelands the federal government created state-controlled territory open to use by white entrepreneurs and settlers. From the first, the nineteenth century's ubiquitous livestock grazing, immigrant herders, and burning by native peoples and graziers seeking to maintain open landscapes were considered threats to the timber supply and watersheds. Grazing, the primary use of the forests at the time of the initiation of the Forest Service, was initially eliminated, then restored under Pinchot as an important economic activityactually worth more than forest production at the time. Forest Service policies allowing grazing favored cattle producers over sheepherders, American-born vs. immigrant, wealthy over poor, and Anglo over Hispanic (Sayre, 2018; Saitua, 2019). Grazing was allowed to grow massively during the first World War with the goal of supplying the war effort, but has declined ever since as land management agencies navigate among multiple competing goals for the forests, and seek to balance grazing and forage (Huntsinger et al., 2010). Unfortunately, in the unpredictable and highly varied weather of the West and California, such a balance is elusive and maximizing flexibility is more in line with current understandings of rangeland vegetation-yet the efforts of the agencies have by and large been stability-oriented, relying on set stocking rates. In addition, the equilibrium theories that underly the seeking of balance also led to an assumption that reducing grazing would lead to the return of the original state, something that has also proven elusive given all the changes that have occurred in these ecosystems and their natural temporal variability (Keeley et al., 2003; Vetter, 2005; Harris et al., 2006; Seastedt et al., 2008; Hobbs et al., 2014; Allen et al., 2019). Finally, the relationship of grazing with the plants and wildlife that have shared these ranges for decades are not well-understood (Barry and Huntsinger, 2021). What is clear is that suppressing indigenous and agricultural burning, and reducing grazing, facilitated the densification of western forests and, depending on location, brush encroachment into grasslands and woodlands.

\section{Early Explorers and Vegetation Dynamics}

Late nineteenth and early twentieth century mountaineers and naturalists observed burning and grazing in Sierran forests and the resulting vegetation dynamics. Clarence King first noted the presence of livestock in the Sierra in 1864 (Gómez-Ibañez, 1977, p. 36). Muir (1911), accompanying a flock of sheep into the Sierra, stated that "almost every leaf that these hoofed locusts can reach within a radius of a mile or two from camp has been devoured." He also commented on indigenous burning to improve hunting grounds. George Sudworth illustrated his report with pictures of the bare forest floor in grazed and burned areas, comparing them to protected areas with lots of understory shrubs and tree regeneration (Sudworth, 1900). He observed several instances of sheepherders setting fires to clear brush to improve the forage supply and make herding easier, noting in one case that 17 fires had been set on the trail of one band of sheep over a distance of 10 miles (p. 556).

Leiberg (1902) attributed the continued existence of "grassy fire glades" to burning and grazing, and noted that when protected from grazing and fire, they rapidly become dense sapling stands. A north coast expedition in 1851 found that such openings in the forests were the only place game could be found for food or their mules could graze-if a glade could not be found the group and the mules went hungry. A group member named George Gibbs wrote that "one of the men in the party and several of the mules starved to death before the trip ended, but the Indians were better acquainted with the location of these oases, as it were, in the midst of desolation, and they maintained regular trails between them." He observed that "[M] ost of these patches if left to themselves would doubtless soon have produced forests, but the Indians were accustomed to burn them annually" (Loud, 1918; Heizer, 1972, p. 230).

William Dudley observed that though most of the pines and firs he saw on his 1895 visit to the Sierra bore fire scars, for some years "no extensive fires had occurred in the region traversed" (Dudley, 1896). Lieberg suspected early miners and indigenous people of having set more past fires, writing that "the aboriginal inhabitants undoubtedly started them at periodic intervals to keep down the young growth and the underbrush. When the miners came, fire followed them" (Leiberg, 1902, p. 40). An analysis of tree ring history in the Sierra conducted in the 1990s led to the conclusion that burning by herders in the 1890s was not necessarily more frequent than that originally carried out by indigenous peoples, but was not as extensive, due to fuel reduction by grazing (Skinner and Chang, 1996, p. 1,058). It seems that in some areas, fire, and grazing were competing for the available fuel. In fact, fire is often part of pastoral and hunting systems around the world because it shifts the vegetation to a state more accessible and more nourishing for ungulate grazers, wild or domestic (Archibald et al., 2012). In both cases, erosion and loss of species can result if the soil is left overly exposed or plants are irreparably damaged. Species and vegetation structure will also likely change with the suppression of either fire or grazing.

Attempts to suppress fire in the early twentieth century led to the first major modern advertising campaign by a government land management agency (Pyne, 1997). During WWI and II preventing fire became conflated with patriotism, with Forest Service posters of Uncle Sam saying "your forestsyour fault-your loss" (Figure 7). In 1918 the Shasta-Trinity Forest Supervisor sent letters to local stockmen who set fires to clear brush and prevent tree encroachment into meadows, quoting President Wilson as follows: "Preventable fire is more than a private misfortune. It is a public dereliction. At a time like this of emergency and manifest necessity for the conservation of national resources, it is more than ever a matter of deep and pressing consequences that every means should be taken to prevent this evil" (New York Times, 1918). The Forest Supervisor goes on to impute that the fact that WWI was going on made the crime of burning especially heinous. He states that it took the equivalent of 400 men working every day for 4 months to suppress man caused fires, and these men were needed at the front. It was therefore the patriotic duty of the 


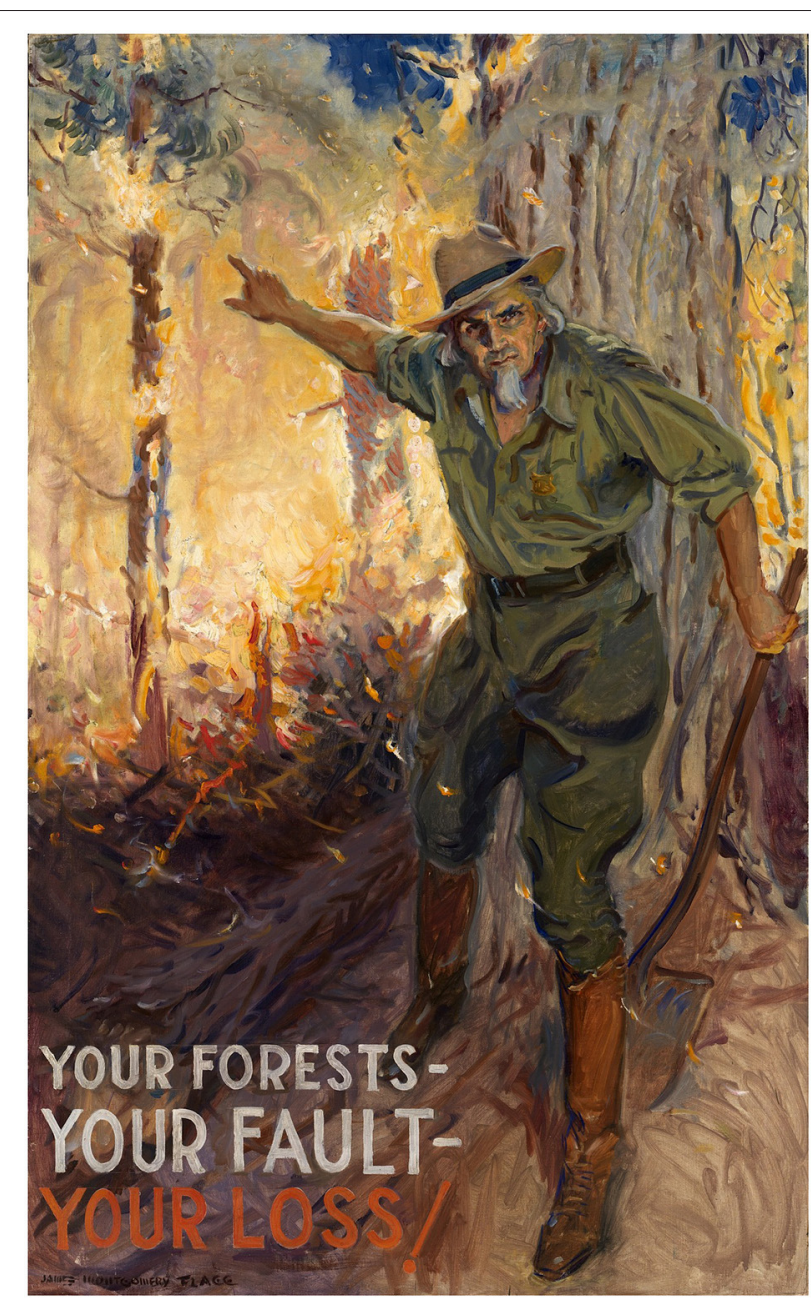

FIGURE 7 | Your forests-your fault-your loss (Flagg, 1934-1943).

stockman to prevent fire (Morrow, 1918; Huntsinger et al., 2010). Eventually, Smokey Bear became the iconic representative of the fire suppression movement. Burning for agriculture and grazing was suppressed, and intentional burning by Native Californians criminalized (Huntsinger and McCaffrey, 1995). On the ShastaTrinity, once grassy slopes are now covered with brush and dense trees (Taylor, 1995). The outcome now seems inevitable: by midMay 2021, 10 fires ignited by lightning were already burning on the forest (Dechter, 2021).

California montane forests have undergone great change, with denser trees and more brush in conifer forests and oak woodlands, and federal forests now have higher fire probabilities than forests in other forms of ownership (Starrs et al., 2018). In Northern California Douglas fir (Pseudotsuga menziesii) trees are encroaching on oak woodlands (Quercus spp. and Notholithocarpus densiflorus) in the foothills and lowlands of the state, increasing oak mortality and reducing biodiversity and essential wildlife habitat (Barnhart et al., 1996; Hastings et al., 1996). The buildup of dried fuels in California's Mediterranean ecosystems is one key driver of the wildfire crisis in the state (Starrs et al., 2018; Keeley and Syphard, 2019). Livestock grazing

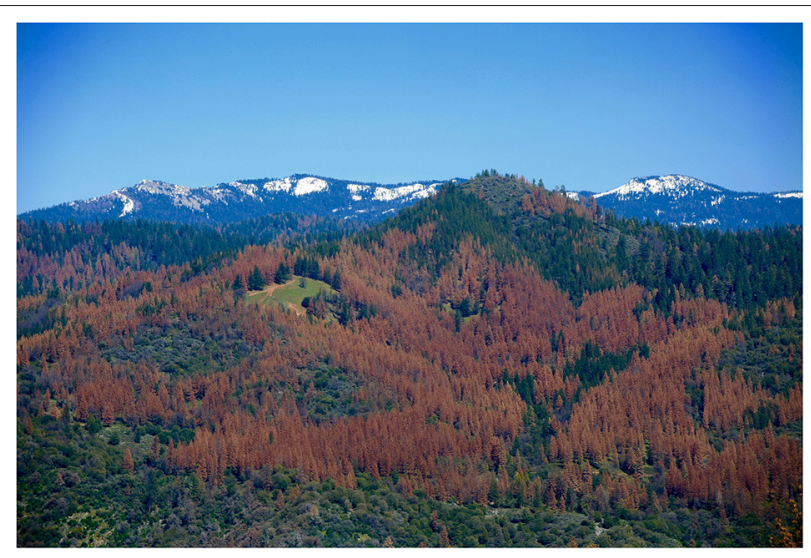

FIGURE 8 | A long period of drought resulted in millions of standing dead trees in the Sierra National Forest in April 2016. Photo: USFS Region 5.

removes fine fuels like grasses and herbs, and in some ecosystems, can restrict shrub encroachment, particularly if annual grazing is initiated when encroaching shrubs are seedlings that are consumed along with grasses (McBride, 1974; Huntsinger, 1997; Russell and McBride, 2003; Moreira et al., 2020). A recent study found that the main link to climate change as a driver at lower elevations along the coast is the buildup of herbaceous material when rainfall is high (Keeley and Syphard, 2019).

Unfortunately, as scientific forest management developed under Fernow, Pinchot, and their ilk, fire came to be seen as a disturbance that prevented the succession of vegetation to the climax state of heavy forest, rich with timber (Huntsinger, 2016). Without burning, the dead plant material deposited by grasses, trees, and shrubs-wood, cones, leaves, and needles-piles up beneath the living vegetation. The unpredictable but sometimes severe and multi-year droughts that California experiences lead to tree mortality over-crowded woody vegetation where competition for water occurs. This leads to increasing amounts of fire-feeding dead woody material, and much of it hyperflammable and well-ventilated standing fuels (Figure 8).

Vast areas of California became occupied by brush, dead material, and overly dense trees that are highly vulnerable to drought, making the fire risk even greater. Mountain meadows are being invaded by trees in many areas (Taylor, 1990; Lubetkin et al., 2017). There are several million ha of burned over areas from the fires of the last 5 years with a recovery trajectory that is unknown because it is not clear how climate change will affect regrowth, with the possibility that a long term or permanent brush state will occur in some areas (Davis et al., 2019; Young et al., 2019; Stewart et al., 2020).

\section{THE TWENTY-FIRST CENTURY FIRESCAPE AND REIMAGINING LIVESTOCK GRAZING}

Livestock grazing is seldom mentioned in media or policy forums as an important way to reduce fire hazard (Daley, 2021), despite widespread biomass-reduction activities by grazed 
TABLE 1 | Definitions of common vegetation treatments in California.

Clearcutting: Cutting of essentially all trees in a location fully exposing the forest floor for the development of a new age class of trees.

Thinning: Tree removal that reduces tree density and competition between trees in a stand. Thinning serves to concentrate growth and vigor in fewer high-quality trees.

Harvest: Cutting, felling, and gathering of forest timber, may include clearcutting or thinning.

Mastication: Vegetation is mechanically "mowed" or "chipped" into small pieces and left on-site reconfiguring a portion of forest biomass from a vertical to horizontal arrangement.

Other mechanical: A variety of forest and rangeland mechanical activities related to fuels reduction and site preparation including piling of fuels including chaining, lop and scatter, thinning of fuels, Dixie harrow, chaining, etc.

Prescribed burning: A fire set intentionally for purposes of vegetation management, using a "prescription" of when burning and air quality conditions are appropriate. May be referred to as control burning.

Cultural burning: Burning practices developed and carried out by indigenous people to enhance the health of the land, including restoration of culturally significant species and landscapes.

Prescribed/ targeted grazing: Managing and husbanding animals for vegetation management, often goats.

Commercial grazing: Grazing livestock for production of food and fiber, primarily cattle and sheep.

domestic livestock, and scattered publications put out by University of California Cooperative Extension (Nader et al., 2007; Rao, 2020; University of California Cooperative Extension (1), 2021; University of California Cooperative Extension (2), 2021; University of California Cooperative Extension, California Invasive Plant Council, Environmental Protection Agency, 2021). New state initiatives to manage fuels include relaxing environmental rules to allow for fuel breaks and prescribed fire, but the role of livestock grazing is usually overlooked. For example, California's Wildfire and Forest Resilience Action Plan, produced in January 2021, includes a large picture of cattle grazing under electrical lines like those responsible for major ignitions, a setting where the removal of biomass by grazing is clearly valuable. While mentioning healthy grasslands and advocating for prescribed burning of them, the report never mentions grazing at all (Forest Management Task Force, 2021). California has extensive lands with flammable fire-adapted vegetation: $82 \%$ of the state is undeveloped including $\sim 20 \mathrm{~m}$ ha of government and $13 \mathrm{~m}$ ha of private land (California Department of Forestry and Fire Protection, 2010). The wildfire crisis apparent calls for the use of every mitigation and prevention tool we have (Table 1), except for the most widespread fuel removal activity in the state.

Each year grazing cattle are estimated to remove at least 5.3 billion $\mathrm{kg}$ of biomass (drywt) from close to the 8 million ha of private California rangelands with available data. On average, that is about $1,500 \mathrm{~kg}$ per ha (Rao, 2020). Amounts of biomass produced and consumed vary by orders of magnitude annually and by region, as do recommended grazing levels (Becchetti et al., 2016). Fire hazard reduction is a side benefit of production of meat and milk_-grazing reimagined as purposeful for removing fuel and altering vegetation structure could emphasize fire-prone locations or vegetation types, targeting areas as needed with more intensive removal (Nader et al., 2007), and combining grazing with burning and clearing. In addition to grazing for livestock production by cows, sheep, and goats, businesses providing grazing services for fire hazard reduction are emerging and flourishing. Some land trusts, parks, and preserves use commercial livestock grazing and/or targeted grazing services to reduce biomass for fire as well as to enhance biodiversity. For example, the East Bay Regional Parks in the San Francisco region (East Bay Regional Parks, 2021). The California Department of Fish and Wildlife provides Excess Vegetation Disposal Permits for commercial livestock grazing to make the purpose of grazing leases clear to the public.

Grazing as a fire-fighting tool faces further challenges in addition to neglect by agencies with vegetation management responsibilities. California range livestock numbers have declined since the 1970 s. While $70 \%$ of livestock forage is provided by California's mostly private annual rangelands (Huntsinger and Bartolome, 2014), public lands, more than $50 \%$ of the land area of the state, also support livestock grazing, especially in summer when high elevation meadows provide rich feed while the grasslands below are dry. While many parks, conservation properties, and reserves use grazing to enhance biodiversity and reduce fire risk, and for a notable number of endangered species grazing is a useful habitat treatment (Barry and Huntsinger, 2021), increasingly conservative stocking rates and exclusion of stock are common on public land that is managed by federal and state agencies. Federal public lands throughout the western United States have experienced a dramatic decrease in livestock numbers during the past two decades. Ostensibly to meet agency conservation objectives, California's public lands managed by the Forest Service (USFS) and the Bureau of Land Management (BLM) have seen a $36 \%$ decline in grazing, measured in animal units on the land per month (AUMs) (Figure 9; Oles et al., 2017), just at the time it is needed.

On some state and park lands, after over a century of grazing, livestock were excluded to meet expectations of wilderness, increase naturalness (Fried and Huntsinger, 1998), or reduce perceived conflicts with wildlife (Barry and Huntsinger, 2021). In other areas landscape fragmentation has made grazing difficult to manage and more costly. Among private landowners, on both rangelands and forest there are an increasing number who are not production or management oriented, preferring to leave the land as "natural" as possible. A significant number of owners have the stated main ownership purpose of land speculation, a number that appears to be growing (Ferranto et al., 2011).

In addition to a fuel and climate problem, intermixing of housing and development with forests and rangelands in California and throughout the West increases risks to property, lives, and human health (Radeloff et al., 2018; Kramer et al., 2019). An estimated one-third of homes in the US are built in or near wildland vegetation and constitute the Wildland Urban Interface (WUI) (Kramer et al., 2019). In California, $75 \%$ of buildings destroyed by wildfire were in a WUI (Kramer et al., 2019). Thus far, land use planning processes have 


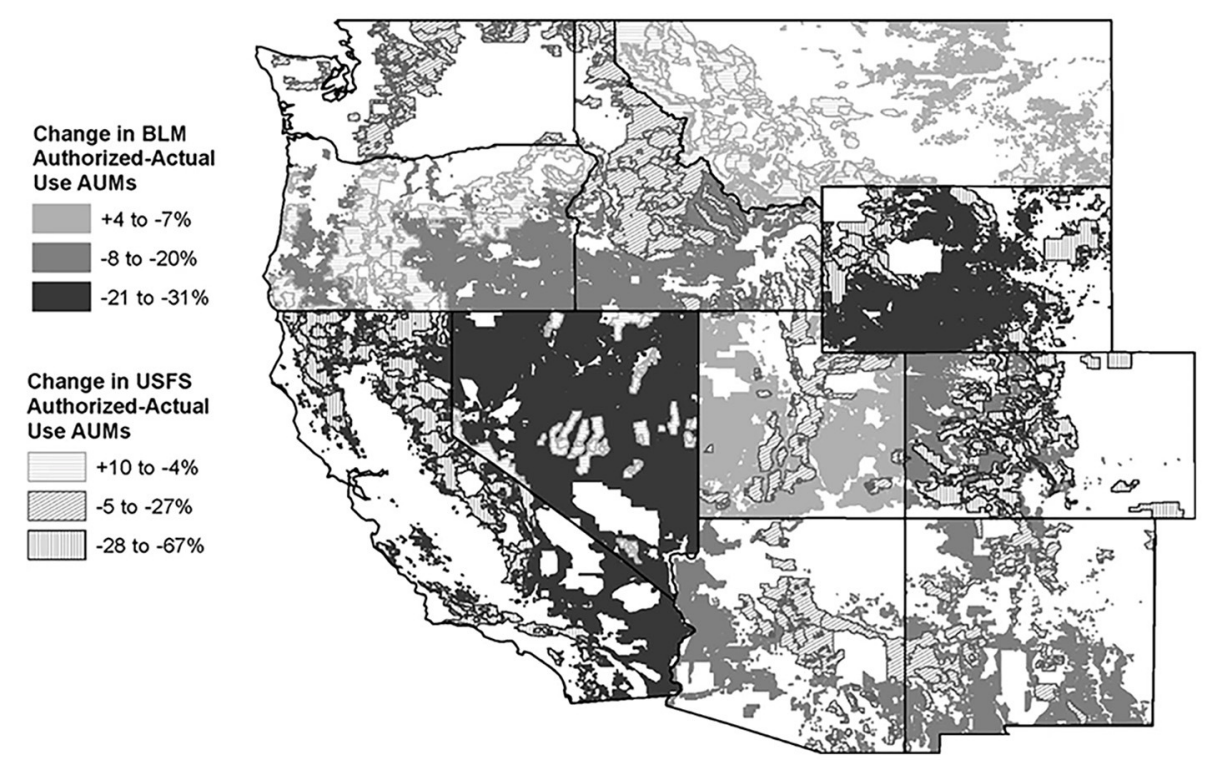

FIGURE 9 | Change in animal unit months (AUM) on public lands in 11 states in the western U.S. between 2000 and 2015 . The lightest color represents slight positive to slight negative changes in AUMs. Darker colors represent increasingly negative changes in AUMs. Solid polygons represent lands administered by the Bureau of Land Management (BLM). Hatched polygons represent lands administered by the U.S. Forest Service (USFS). Data were sourced from BLM and USFS annual reports (Oles et al., 2017).

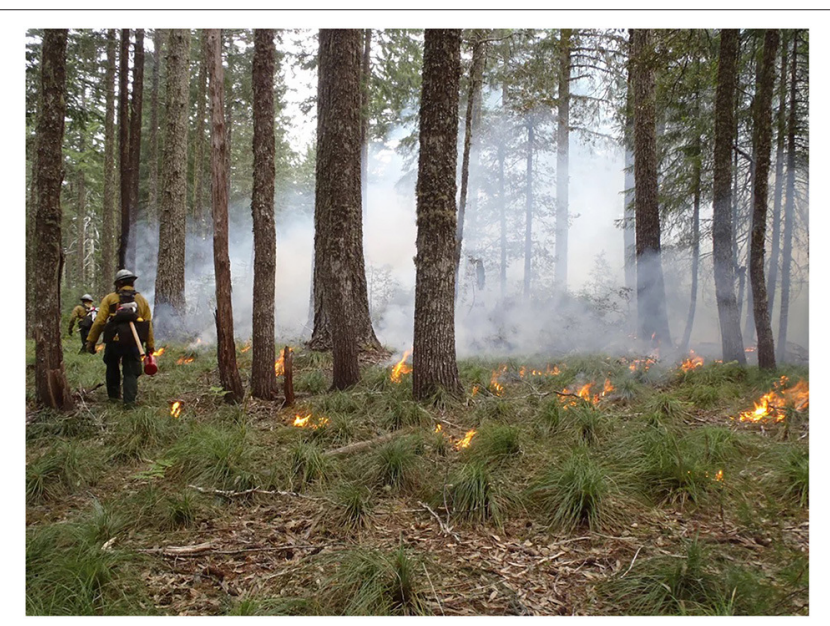

FIGURE 10 | In understory burning, one goal is to prevent harm to the larger trees, while suppressing growth of shade tolerant conifers that would crowd the stand, and create openings diverse species. In a cultural burn, goals may include enhancing culturally significant species and landscapes, and in some cases, influencing plant growth form for weaving or carving. The understory here contains a high density of beargrass (Xerophyllum tenax), a valued basketry resource requiring fire to promote desired leaf growth (Photo: Frank Lake, US Forest Service).

been inadequate to prevent the creation and expansion of the WUI. Promotion of defensible space, clearing around homes, and hardening of homes against ignition are strategies widely promoted to homeowners, and can reduce home loss, as can adequate roads for fire-fighting access and other factors. Recently,
California fires have burnt through WUIs and into neighboring communities, using houses as a source of well-dried fuels, and leveling blocks of homes and shopping centers (Kramer et al., 2019).

California's fire problems are not unique. Traditional agricultural systems offer some insights into how grazing might be used. Land abandonment is a frequent topic in Europe's Mediterranean regions, and wildfire is a common and much feared consequence (Collins et al., 2013; Moreira et al., 2020) as farmers and graziers leave. Grazing and agriculture are often unabashedly considered key to reducing fire hazard in southern Europe (Lovreglio et al., 2014; Colantoni et al., 2020; Damianidis et al., 2020; Moreira et al., 2020; https://www. mosaicoextremadura.es/en/home-en/). Spain and Portugal offer an example of the use of grazing and tree management in to create a fire-resistant landscape. In the southern Iberian Peninsula, grazing is part of traditional agricultural systems with a histories of more than a 1000 years, such as the Spanish dehesa and Portuguese montado (Bugalho et al., 2011). Featuring oaks that are pruned to have no low branches, well-spaced trees without continuous crown fuels, and an understory of annual grasses (many common in California), they are generally heavily grazed by combinations of sheep, goats, cattle, and pigs, as well as wild grazers like red deer. Every 10 years or so, unpalatable brush is cleared or the understory is cultivated with a grain crop. The result is one of Spain's most fire resistant landscapes (Ortega et al., 2012). Removal of grazing or cessation of understory clearing has been found to increase fire hazard and reduce biodiversity (Joffre et al., 1999; Tarrega et al., 2009). For many communities, forms of agro-sylvo-pastoralism are a key strategy used to create productive firebreaks. On the other hand, the vast 
eucalyptus and pine forest plantations common to Portugal and Spain, growing at high density and with continuous fuels, are among the most likely vegetation to burn and have fueled recent catastrophic fires (Fernandes et al., 2016).

\section{Fire Hazard Reduction Efforts and Reimagining Livestock Grazing}

At the present time in California, in the media and popular outlets the emphasis is on prescribed burning, promoted as a natural part of the ecosystem (Table 1). An answer to our fire problem, in these terms, is to restore frequent fire to the ecosystem, substituting for the indigenous and natural burning that once reduced brush and thinned trees, creating more open grassland and forest. The United States Forest Service, the National Park Service, CalFire (the state fire and resource management agency), landowner groups, and Native Californians have embraced prescribed burning, intentional or allowed burning for management purposes that takes place within a prescription that includes a number of variables including weather and environmental characteristics. Cultural burning, burning practices developed by indigenous people to enhance the health of the land, including restoration of culturally significant species, also seems to be increasing in agency and public acceptability (Sommer, 2020; Lake, 2021; Marks-Block et al., 2021; Figure 10). Invasion of conifers and shrubs into grasslands burned regularly under indigenous management means that restoration of burning practices is key to restoring traditional landscapes and ecosystems (Keeley, 2002; Evett and Cuthrell, 2013). In the last decade indigenous groups have actively sought access to land and restoration of indigenous management practices, with cultural burning a common goal, augmented with hand clearing when required to restore conditions for safe burning (Sommer, 2020).

The argument is made that prescribed burning is the natural way to remove fuels and restore a more fire-resilient landscape, but this debatable. The climate is warming, highly flammable non-native annual grasses are common, there is fuel

TABLE 2 | Comparison of fuel reduction treatment alternatives in California.

\begin{tabular}{|c|c|c|c|c|c|c|}
\hline Treatment & Application & Cost & Benefits & Constraint $^{a}$ & Products & Extent (est) \\
\hline Manual & $\begin{array}{l}\text { Clear or prune } \\
\text { herbaceous and } \\
\text { woody plants }\end{array}$ & $\$ 1,980 / \mathrm{ha}^{\mathrm{b}}$ & $\begin{array}{l}\text { Low impact, targeted. Steep } \\
\text { slopes. }\end{array}$ & $\begin{array}{l}\text { High cost, small areas. } \\
\text { Fuel may be left on site or need } \\
\text { disposal. }\end{array}$ & No & Minimal \\
\hline Mastication & $\begin{array}{l}\text { Chop and grind } \\
\text { surface and ladder } \\
\text { fuels by machine. }\end{array}$ & $\$ 250-2,500 / \mathrm{ha}^{\mathrm{c}}$ & $\begin{array}{l}\text { Targeted, masticated areas can } \\
\text { be more safely burned to remove } \\
\text { fuel }\end{array}$ & $\begin{array}{l}\text { Fuel left on site but converted to } \\
\text { horizontal structure }\end{array}$ & No & Minimal \\
\hline $\begin{array}{l}\text { Mechanical } \\
\text { thinning or } \\
\text { harvest }\end{array}$ & $\begin{array}{l}\text { Tree removal, } \\
\text { reducing density, } \\
\text { or cutting for } \\
\text { timber }\end{array}$ & $\begin{array}{l}\$ 90-2,500 / \mathrm{ha}^{\mathrm{b}} \\
\text { Some costs may } \\
\text { be offset by timber } \\
\text { sales }\end{array}$ & $\begin{array}{l}\text { Costs offsets from timber. } \\
\text { Only method to remove } \\
\text { established trees (besides } \\
\text { wildfire) }\end{array}$ & $\begin{array}{l}\text { Soil disturbance } \\
\text { Can meet fuels reduction targets. } \\
\text { Accompany with burning or } \\
\text { mastication to reduce surface } \\
\text { fuels. }\end{array}$ & $\begin{array}{l}\text { Wood products, } \\
\text { saw logs, chips }\end{array}$ & $\begin{array}{l} \pm 1 \text { million } \\
\text { ha/yeare }\end{array}$ \\
\hline Prescribed fire & $\begin{array}{l}\text { Reduce ground } \\
\text { and surface fuel, } \\
\text { including dead } \\
\text { wood, invasives. }\end{array}$ & $\begin{array}{l}\text { Variable Cost } \\
\$ 7-2,700 / \text { ha }^{d}\end{array}$ & $\begin{array}{l}\text { Lower cost at scale. Benefits } \\
\text { fire-adapted plants. Selective of } \\
\text { fuels by intensity. }\end{array}$ & $\begin{array}{l}\text { Smoke, regulations, site } \\
\text { conditions, air quality, liability, } \\
\text { risk-especially with ladder fuels. } \\
\text { Selective by fuel quality. }\end{array}$ & No & $\begin{array}{l} \pm 45,000 \text { ha/year } \\
\text { (increasing) }\end{array}$ \\
\hline $\begin{array}{l}\text { Prescribed/ } \\
\text { Targeted grazing }\end{array}$ & $\begin{array}{l}\text { Reduce ground } \\
\text { and surface fuels, } \\
\text { control invasive } \\
\text { species }\end{array}$ & $\begin{array}{l}\text { Variable } \\
\text { Cost } \\
\$ 1,090-2,700 / \mathrm{ha}^{\mathrm{e}}\end{array}$ & $\begin{array}{l}\text { Low risk, few regulations. } \\
\text { Selective by species and } \\
\text { intensity. } \\
\text { Different livestock for different } \\
\text { goals. }\end{array}$ & $\begin{array}{l}\text { Higher cost, small areas. Fences, } \\
\text { water, maybe herder needed. } \\
\text { Prune up to 4-6 feet off the } \\
\text { ground. Large woody vegetation } \\
\text { not removed, desired plants may } \\
\text { be. }\end{array}$ & $\begin{array}{l}\text { Often a specialized } \\
\text { service rather than } \\
\text { for producing } \\
\text { meat or milk. } \\
\text { Often goats }\end{array}$ & $31,000 \pm$ ha/yearg \\
\hline $\begin{array}{l}\text { Commercial } \\
\text { grazing }\end{array}$ & $\begin{array}{l}\text { Annual } \\
\text { herbaceous } \\
\text { biomass removed. } \\
\text { Trampling and } \\
\text { grazing may } \\
\text { impede shrub } \\
\text { spread or } \\
\text { regrowth. }\end{array}$ & $\begin{array}{l}\$ 0 \text { to revenue; } \\
\text { cost-sharing, } \\
\text { reduced rent for } \\
\text { infrastructure help, } \\
\text { complex plans. }\end{array}$ & $\begin{array}{l}\text { Lowest cost if infrastructure } \\
\text { present. } \\
\text { Annual treatments easy. Low } \\
\text { risk. Brush seedlings may be } \\
\text { removed /suppressed, annual } \\
\text { grasses eagerly consumed. }\end{array}$ & $\begin{array}{l}\text { Requires fences and water. } \\
\text { Forage must meet livestock } \\
\text { needs or supplement is needed. } \\
\text { Mature woody vegetation not } \\
\text { removed. May consume desired } \\
\text { plants. Limited by livestock } \\
\text { production needs, bottom line. }\end{array}$ & $\begin{array}{l}\text { Food and animal } \\
\text { products }\end{array}$ & $\begin{array}{l}16 \text { million } \pm \\
\text { ha/year }\end{array}$ \\
\hline
\end{tabular}

Please note that local assessment is needed to determine how each technique works on a given site.

${ }^{a}$ All treatments produce greenhouse gas emissions, all may enhance biodiversity or meet other resource management objectives.

${ }^{b}$ Lasaux and Kocher (2006); http://cecentralsierra.ucanr.edu/files/88262.pdf.

c United States Department of Agriculture (2005).

${ }^{d}$ Quinn-Davison and Stackhouse (2019).

e Macon (2014).

${ }^{f}$ California Air Resources Board (2021).

${ }^{g}$ Roger Ingram (pers. comm.) UCCE emeritus, August 6, 2021). 
accumulation and vegetation change in many areas, and housing is mixed with forests, woodlands, and shrublands (Yoon et al., 2015). To reduce the risk, burning when fuels are not at their driest, often outside of the natural fire season, is common. Burning out of season affects plants and animals in different ways than burning within the fire season they have evolved with. Cultural burning is also difficult to conduct within the traditional season because of ecosystem change and risk to buildings and infrastructure, making compromise part of the picture. Yet deliberate burning is needed to develop a more fire resistant landscape. Further, cultural burning offers indigenous knowledge to inform burning efforts, and is a heritage activity that cannot only address wildfire risk, but contribute to the revitalization of indigenous cultures.

Around 45,000 ha of California vegetation was burned deliberately in 2019, a considerable increase from the $<16,000$ ha burned each year since 2007 , but only about $0.14 \%$ of the $33 \mathrm{~m}$ ha of wildland in California, and 3\% of the nearly 1.7 million ha burned in the 2020 wildfires (Table 2). About $37 \%$ of the 2019 burned area was in forests, the rest on rangelands (California Department of Forestry and Fire Protection, 2010; California Air Resources Board, 2020). Land management agencies and private rangeland and forest landowners are eager to do more. Landowner-driven prescribed burning associations are being reinstated and resuming higher levels of activity (Hagarty, 2020, October 19). The state fire agency is working to streamline the permit process for such burns. But prescribed burning can be costly, with extensive planning, insurance, and monitoring needed. Multiple regulations from more than one agency, as with fire agencies and air quality entities, slow the process. The need to burn under ideal weather, fuel, and air quality conditions makes the window for burning small, resulting in delays. Fears of liability hamper private landowners. The permitting agencies have also not been overly receptive to prescribed burning not implemented by them (Hagarty, 2020, October 19; Susan Kocher (pers. comm.) UCCE, August 6, 2021.) and yet funding has been tight for agency-conducted vegetation management activities. The premier fire-fighting and forestry licensing agency, the California Department of Forestry and Fire Protection or CalFire, is typical-spending on prevention lags far behind spending on suppression because it is easier to get funding to fight fires than to prevent them (Figure 11). And, often the places that need burning the most are the most dangerous to burn (Wood, 2020). Getting prescribed burns done on schedule can be cumbersome. It requires a smoke management plan to be filed with the local air quality district and mandates a burn plan be filed with the corresponding fire agency. Considering that burned areas need to be reburned eventually to maintain the effects of burning, with all the barriers and the cost, there is a possibility that instead a burn will prove to be a one-time treatment with limited duration of effect (Fernandes and Botelho, 2003).

Other vegetation management strategies should be promoted as much as prescribed and cultural burning, including grazing. They include burning, clearing, and grazing (Table 2). The federal government, for example, working with the state, has introduced a forest thinning program with the goal of scaling up thinning and clearing to $\sim 400 \mathrm{t}$ ha of forest per year, about $0.03 \%$

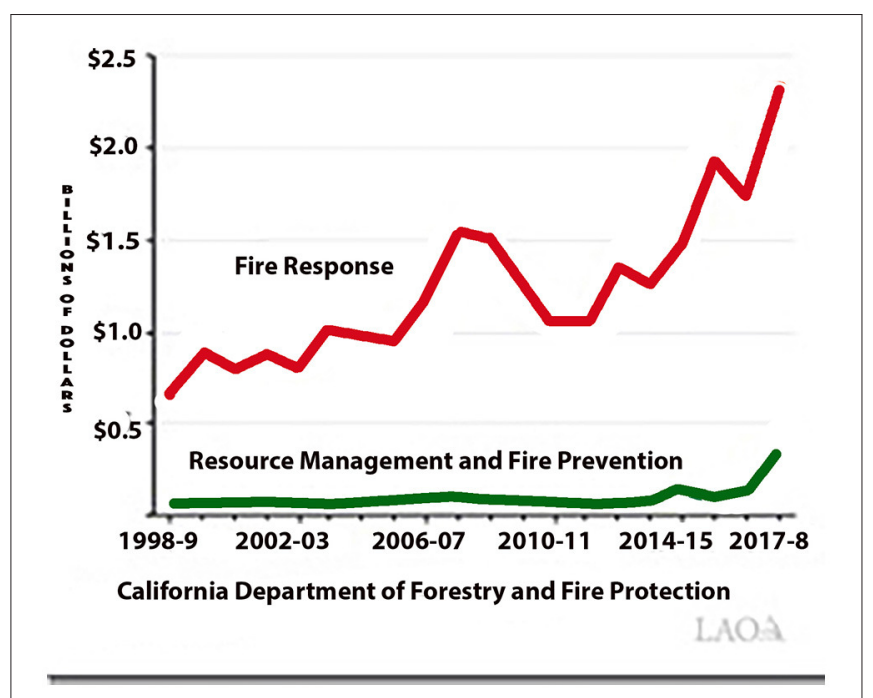

FIGURE 11 | Spending on fighting fire vs. preventing fire, CalFire (Legislative Analyst's Office, 2018).

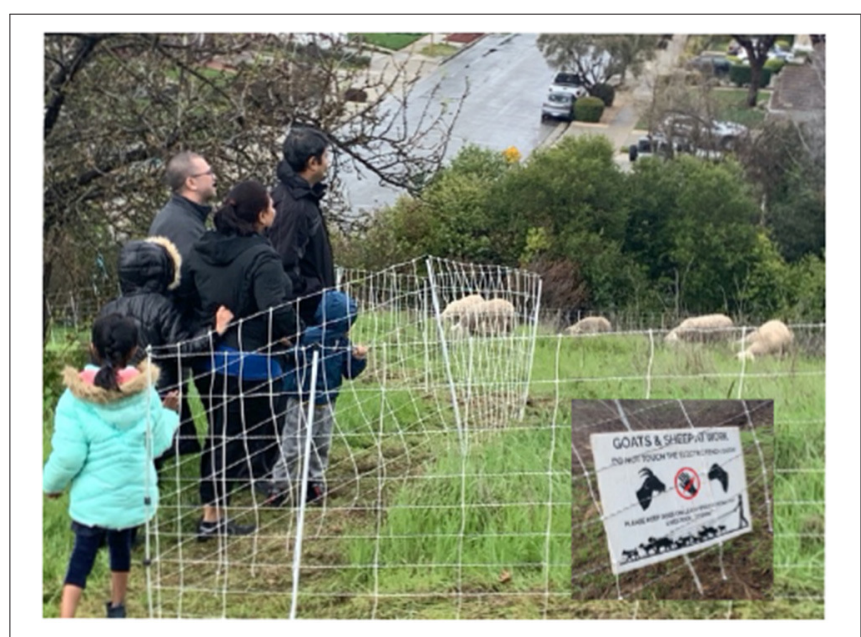

FIGURE 12 | Targeted grazing for fuels reduction using sheep in a suburban park in San Jose, California. Photo: S. Barry.

of California's forestland, by 2025 using brush clearing, logging, and prescribed fires (United States Forest Service and State of California, 2020). California has budgeted \$1 billion for 20202021 to increase prescribed fire on state owned lands and develop a network of fire breaks (Forest Management Task Force, 2021).

Fires, aside from lightning strikes directly to trees, generally start in fine, dry fuels, where they spread swiftly. Early in the season, grasslands, and shrublands dry first, becoming fuel for some of the state's most destructive wildfires (Weill, 2018). Grasses are $1 \mathrm{~h}$ fuels, drying in $1 \mathrm{~h}$ of hot and dry weather, while trees are 100-1,000 h fuels (Sikkink et al., 2009). Grasses are standing dry material, with plenty of oxygen mixed with dried fuel. Fine fuels from dry herbaceous vegetation and the small plant materials that fall to the forest floor act as kindling, leading 
to the burning of larger and larger fuels until the fire can burn huge trees. Changing continuous to discontinuous fuels is crucial (Weatherspoon and Skinner, 1996). Tree canopy is fine fuel too, so creating breaks in the canopy and breaks that reduce the ability of ground fires to reach the canopy are important fire prevention and fighting strategies (Nunamaker et al., 2007). Unfortunately, the aggressive, invasive non-native annuals that now dominate most California grasslands are continuous fuel that allow fires to spread across the landscape. They invade shrublands and burned or cleared forest areas, including fuel breaks (Keeley et al., 2003; Merriam et al., 2006).

\section{Reimagining Grazing}

Commercial livestock grazing is the predominant land use and the most widespread vegetation management activity in California, occurring on about 12 million hectares of public and private lands. Livestock producers have strong interest in integrating grazing and prescribed burning for vegetation management, reducing shrub encroachment, and improving forage, as well as reducing fire hazard (Hagarty, 2020, October 19; California Cattlemen's Association, 2021). Another advantage of using commercial grazing is that it is relatively inexpensive because the owner is making an income from the enterprise. Production-oriented grazers can charge less or even pay for decent forage when infrastructure like fences and water points are adequate. At the same time, livestock producers must match livestock needs with forage quality and availability, infrastructure, and animal handling practices. Planning complex grazing treatments, or grazing at high intensity, will sometimes incur costs and reduce income. Subsequently, grazing for fire prevention may come at a cost, though likely lower than any other technique we are aware of.

There have been attempts to evaluate the role of commercial livestock grazing in reducing fire hazard (Launchbaugh et al., 2008), but to date studies have focused on lands grazed primarily for production purposes, limiting options for management. For example, one researcher lamented that the ranchers providing cattle to graze his sites for research into beneficial grazing effects on wildlife habitat would simply not graze hard enough because they feared weight loss in the cattle (Germano et al., 2011). In California, livestock grazing tends to be light to moderate to maintain a herd size that be healthy through periodic drought. Regardless of fire risk, the grazing in an even a highly fireprone area may not be intense enough to always make the optimum impact. Traditional practices will need to be re-thought when emphasis shifts to fire hazard management. For example, many ranchers whose animals graze wetter or higher elevation rangelands in the summer have historically tried to leave forage behind for the return of the herd in Fall. The dry forage supports cattle before unpredictable fall germinating rains facilitate new forage growth (Barry, 2021), but this practice, unfortunately, leaves standing dry biomass on the ground. As a solution, left behind forage could be broken into discontinuous units separated by areas fully grazed before the livestock leave. Another option is supplementation instead of dry forage in the fallagain an increased cost that could be compensated for active fuel reduction. In short, be most effectively used for fire hazard reduction, grazing will need to be planned for purposefully controlling fuels, and some practices will need to be incentivized because of higher costs to the producer.

Goat and sheep grazing companies are popping up all over the state offering targeted or prescribed grazing for specific purposes (Table 2). The use of small ruminants for targeted grazing for fuels management tends to be more acceptable to the public. The public see a mob of goats or sheep crowded in a small area munching on vegetation and recognize the activity as a service (Figure 12). They do not find goats or sheep intimidating, and may be unaware that such animals may eventually be slaughtered. Many targeted grazers do not participate in meat or milk production and do not obtain income from marketing animal products, so putting weight on the animals is not a priority, allowing greater flexibility in grazing intensity. In addition, managing certain fuels may best be accomplished with a class of animals like older wethers (castrated male goats or sheep) that have little value for livestock production.

Grazing for fuels management in California is often associated with such small ruminant prescribed herbivory or targeted grazing, which is conducted as a service for a per acre cost. The cost is relatively high compared to commercial grazing, but not hand clearing, which may be the only other option. Grazing infrastructure such as fencing is often not available and the targeted grazer must provide temporary fencing and livestock water. Depending on the setting, animals generally need a herder to ward off dogs and predators, and to maintain temporary fences that are irregularly breached. Sometimes the vegetation to be controlled is not of adequate quality to support the livestock, and supplemental feed is required.

\section{Different Animals and Different Regions}

The characteristics of the animals and of the ecosystem affect what can be done and how it should be done with grazing. Knowledge of dietary preference and grazing patterns is key to developing grazing plans for fire hazard reduction and biodiversity enhancement. Different breeds and species may consume different things and forage differently; animal experience with particular ecosystems may also be a factor. Goats prefer brush and tolerate secondary plant compounds better, sheep prefer more broadleaves, and cows are basically grass vacuum cleaners. Goats and sheep are excellent for steep or rocky slopes, smaller areas around homes and development, and brush control. Extensive grasslands are ideal for cattle, as it can be not only less costly, but they are easier to fence in, not as susceptible to predators, and one cow consumes as much as 5 goats. Grazing different kinds of livestock together might be applied in some situations.

The various approaches each have their benefits and can be combined in innovative ways. While herbicide and hand treatments leave dead, flammable plant material in situ, grazing animals consume the material and process it at the site, converting it into food and fertilizer. If trees are palatable, livestock may browse the lower branches, breaking up fuel ladders that might carry fuel into the canopy. Annuals and some shrubs return with the winter's rainfall, but commercial 
TABLE 3 | Examples of fire and grazing relationships in 4 shrub types in four regions of California [General references: Sampson and Jespersen (1963), United States Department of Agriculture (2021)].

\begin{tabular}{|c|c|c|c|c|c|c|c|}
\hline Brush type & Location & Target species & Fire dynamics & Grazing management & Conservation value & Hazard & Grazing references \\
\hline $\begin{array}{l}\text { Coastal montane } \\
\text { chaparral } \\
\text { (Chamise, } \\
\text { Adenostoma } \\
\text { fasciculatum; } \\
\text { Manzanita, } \\
\text { Arctostaphylos } \\
\text { spp.; Scrub oak, } \\
\text { Quercus } \\
\text { dumosa) } \\
\text { Interior chaparral } \\
\text { (Chamise, } \\
\text { Adenostoma } \\
\text { fasciculatum; } \\
\text { Manzanita spp., } \\
\text { Arctostaphylos } \\
\text { spp.; } \\
\text { Ceanothus) }\end{array}$ & $\begin{array}{l}\text { Coastal ranges } \\
\text { Ring around } \\
\text { central valley } \\
\text { occurs with oak } \\
\text { woodland }\end{array}$ & $\begin{array}{l}\text { Chamise, } \\
\text { Adenostoma } \\
\text { fasciculatum }\end{array}$ & $\begin{array}{l}\text { Fire intensity, time and } \\
\text { interval control species } \\
\text { composition and diversity. } \\
\text { Dense stands require prefire } \\
\text { treatment to reduce fuels for } \\
\text { safety. Early spring burning } \\
\text { can promote vigorous } \\
\text { resprouting. Small fires, } \\
\text { frequently spread may } \\
\text { reduce large catastrophic } \\
\text { wildfire events. Herbaceous } \\
\text { annuals and perennials } \\
\text { germinate post-fire. Erosion } \\
\text { may be an issue on steep } \\
\text { slopes. }\end{array}$ & $\begin{array}{l}\text { Grazing not effective in } \\
\text { dense mature stands. } \\
\text { Young chamise readily } \\
\text { consumed by goats - in one } \\
\text { case chamise made up } \\
70 \% \text { of the goat diet } \\
\text { (Sidahmed et al., 1978). } \\
\text { Goats can retard regrowth } \\
\text { post-fire and support } \\
\text { maintenance of fuel breaks. } \\
\text { Greater livestock utilization } \\
\text { of Adenostoma is supported } \\
\text { with supplementation. } \\
\text { Animals lose condition on } \\
\text { chaparral alone. Grazing } \\
\text { sprouts intensively after fire } \\
\text { can cause significant shrub } \\
\text { mortality; young growth is } \\
\text { preferred, spring grazing } \\
\text { often recommended. }\end{array}$ & $\begin{array}{l}\text { High conservation value } \\
\text { with diversity of age } \\
\text { class and species. Low } \\
\text { conservation value } \\
\text { within dense stands }\end{array}$ & $\begin{array}{l}\text { Decadent stands are } \\
\text { highly flammable. High } \\
\text { intensity fire from crown } \\
\text { fires are typical. Fire } \\
\text { impacts include smoke } \\
\text { and post-fire debris flow. }\end{array}$ & $\begin{array}{l}\text { Sidahmed et al., 1978, } \\
\text { 1982; Green et al., } \\
\text { 1979; Barro and } \\
\text { Conard, } 1991 \text { Minnich } \\
\text { and Franco-Vizcaíno, } \\
\text { 2003; Narvaez et al., } \\
\text { 2011; Moreno and } \\
\text { Oechel, } 1991\end{array}$ \\
\hline $\begin{array}{l}\text { Coastal } \\
\text { transition }\end{array}$ & $\begin{array}{l}\text { Coastal } \\
\text { grasslands, } \\
\text { central to } \\
\text { northern } \\
\text { California. } \\
\text { Re-colonizer in } \\
\text { coastal sage } \\
\text { scrub and } \\
\text { chaparral } \\
\text { post-fire. }\end{array}$ & $\begin{array}{l}\text { Coyote brush, } \\
\text { Baccharis pilularis }\end{array}$ & $\begin{array}{l}\text { Baccharis increases in } \\
\text { absence of fire and grazing. }\end{array}$ & $\begin{array}{l}\text { Baccharis increases in } \\
\text { absence of grazing. Grazing } \\
\text { and trampling limit invasion } \\
\text { or regrowth in grassland }\end{array}$ & $\begin{array}{l}\text { Supports coastal scrub } \\
\text { reestablishment. } \\
\text { Invades high quality } \\
\text { habitats like coastal } \\
\text { prairie. }\end{array}$ & $\begin{array}{l}\text { Increased fire hazard, } \\
\text { more intense fire with } \\
\text { shrub encroachment }\end{array}$ & $\begin{array}{l}\text { Biswell et al., 1952; } \\
\text { McBride and Heady, } \\
1968 \text { (https://www.fs. } \\
\text { fed.us/database/feis/ } \\
\text { plants/shrub/bacpil/all. } \\
\text { html) }\end{array}$ \\
\hline $\begin{array}{l}\text { Soft chaparral } \\
\text { (coastal sage } \\
\text { scrub, Artemisia } \\
\text { californica) }\end{array}$ & $\begin{array}{l}\text { Southern } \\
\text { California coastal } \\
\text { terraces, plains, } \\
\text { and foothills }\end{array}$ & $\begin{array}{l}\text { Annual grasses, } \\
\text { exotics }\end{array}$ & $\begin{array}{l}\text { Fire adapted, } 30-150 \text { year } \\
\text { return interval but } \\
\text { suppression and fine fuels } \\
\text { (annual grasses) result in } \\
\text { large fires, too frequently } \\
<20 \text { years. Fire not followed } \\
\text { by grazing slows } \\
\text { regeneration to shrubs. }\end{array}$ & $\begin{array}{l}\text { May be managed to benefit } \\
\text { threatened shrubs by } \\
\text { removing flammable annual } \\
\text { grasses, as shrubs are not } \\
\text { highly palatable, but more } \\
\text { study needed. Timing of } \\
\text { treatment seems to matter, } \\
\text { with grazing concentrated } \\
\text { during green grass growth } \\
\text { period. Unmanaged } \\
\text { browsing (sheep and goats) } \\
\text { detrimental. }\end{array}$ & $\begin{array}{l}\text { High conservation value } \\
\text { supporting numerous } \\
\text { endemic species }\end{array}$ & $\begin{array}{l}\text { Brush does not } \\
\text { accumulate high fuel } \\
\text { loads, non-native annual } \\
\text { biomass increases fire } \\
\text { risk }\end{array}$ & $\begin{array}{l}\text { Bradbury, 1978; Conlisk } \\
\text { et al., 2016; Allen et al., } \\
2019\end{array}$ \\
\hline
\end{tabular}




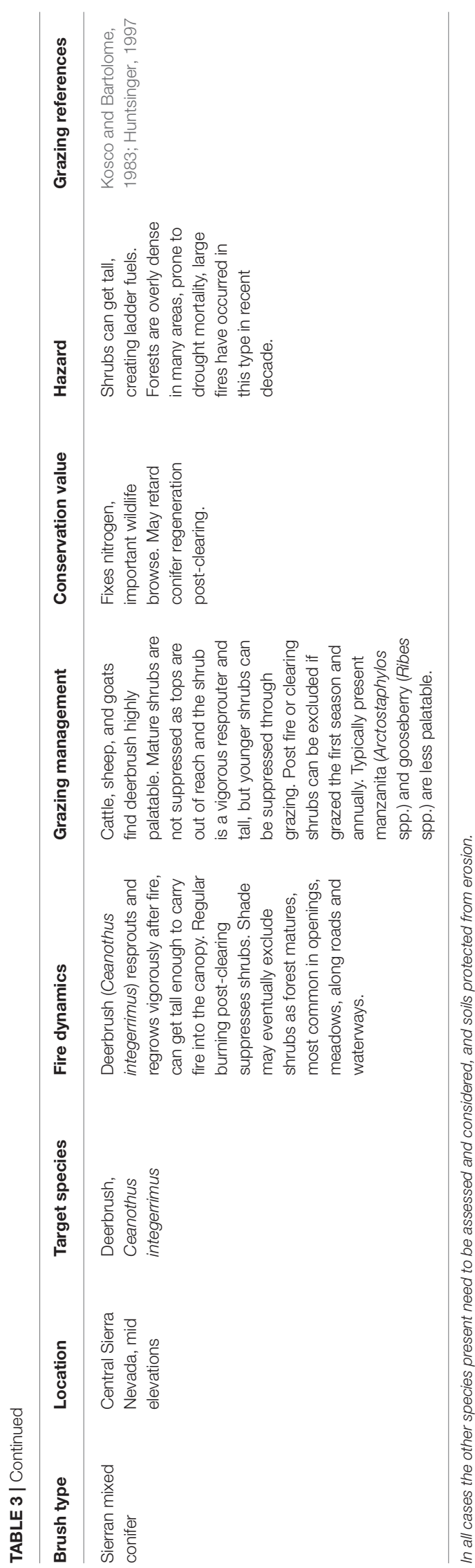

grazing can predictably be applied every year, extending the effects of more sporadic treatments (Fernandes and Botelho, 2003). It also makes it safer for future prescribed burning. Regrowing plants and shrubs are highly nutritious and often, though not always, suppressible by livestock (Huntsinger, 1997). By reducing the ratio of woody to non-woody vegetation components, the landscape becomes literally more palatable for livestock and wildlife. Prescribed burning and grazing do share some limitations: mature woody overgrowth is not so feasible for removal by prescribed burning or grazing, and mechanical or manual treatments often have to be applied first.

Different regions and vegetation types have different vegetation dynamics, and different potential for grazing and fire management, calling for different approaches. Effectiveness and practicality vary by location, vegetation type, animal type, and even the characteristics and experience of individual animals and breeds. In a given year, weather may shape outcomes, as will the timing, intensity, and duration of grazing treatments. Availability of different kinds of animals and experienced producers also varies by location. Much needed information is clearly lacking, but in fact the risks of using grazing are low, and grazing practices are easily adapted as needed.

The applicability of various practices will vary with species, vegetation type, and location (Table 3 ). Ultimately grazing management should be adaptive, and outcomes monitored, as existing information is limited. Talking to local livestock managers, Extension agents, NRCS, and service grazers is an excellent way to start. Various publications provide further guidance on grazing management and illustrate the variation among regions and ecosystems (Nader et al., 2007; Ingram et al., 2013; Lovreglio et al., 2014; Spiegal et al., 2016; University of California Cooperative Extension, California Invasive Plant Council, Environmental Protection Agency, 2021).

\section{CONCLUSIONS}

While professional foresters and agency land managers once considered intentional burning a hostile act and damaging to forests, and livestock grazing a danger to ecosystems, there is considerable evidence that with good management, neither of these things is true. Thanks to the efforts of many and a lot of research, prescribed and cultural burning are gaining in acceptance, even to the point where is has been stated that the agencies will encourage landowners and others to conduct burns with training and permits. The same cannot be said about livestock grazing, yet it needs to be.

California faces a massive fire problem, and our most active fuel managers should not be left in the barn. California's current firescape is increasingly a result of land abandonment, with vegetation and landscapes tended by Native Californians for thousands of years left largely to fend for themselves in the twentieth century. Now more than ever highly fire-prone land is left unstewarded. Removal of grazing from lands grazed for 200 years leads to vegetation change that may not only support fire, but degrade habitat for an array of species. Terming a 


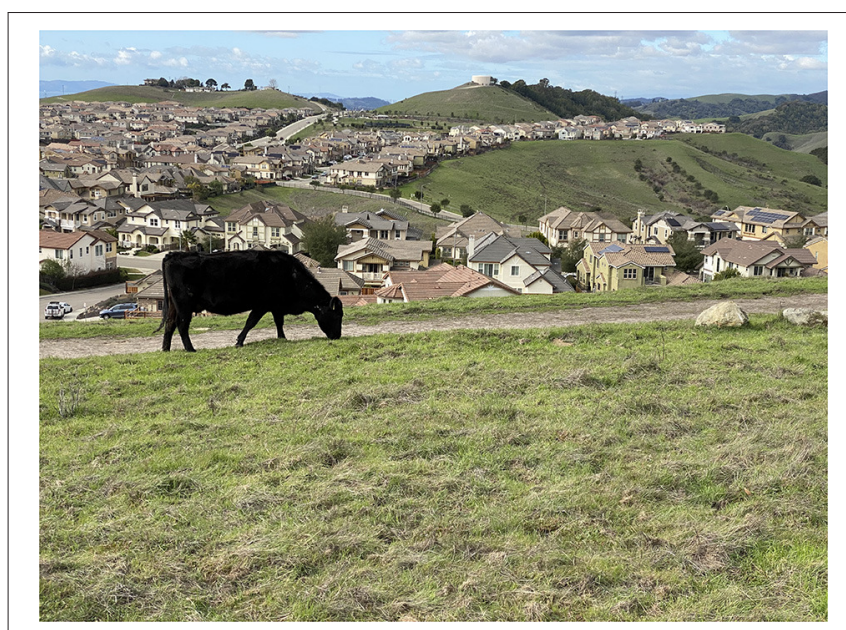

FIGURE 13 | Cattle grazing the Dublin Hills Regional Park, Alameda County, California remove significant fine fuel from the landscape. Once livestock are removed, as in many places in the world, land abandonment has allowed fuels to grow abundantly, leaving highly ignitable, standing dry grass through the summer and fire season. Photo: S. Barry.

continent a wilderness was indeed a late nineteenth century misnomer built on colonial ideologies, unknowingly carried into the twentieth century embedded in preservation initiatives, and still very much a factor today. Yet there is no reason to believe that hands-off management or protecting ecosystems will result in any recognizable recovery. Without restoration of previous ecosystems as a reasonable target, innovation in the face of novel ecosystems and climate is needed (Hobbs et al., 2014).

Forest management practices imported from western Europe emphasized harvesting and planting trees for sustainable timber production, but ignored the role of fire, treating it instead as a disturbance that interferes with an orderly process of vegetation development (Huntsinger, 2016). Efforts to preserve and protect forests run aground on the need for indigenous practices and cultures that created them, and until now, public forests in particular seemed abandoned when it comes to the human and fire role. Those living in proximity to National Forests and overgrown public lands can be fearful of vegetation conditions that seem to be deteriorating into a major fire hazard, while at the same time, they feel powerless to do anything about it. Native Californians are actively pursuing opportunities to restore traditional management practices to the land, but with the changing climate and huge areas that have shifted to unprecedented vegetation conditions, all tools must be brought to bear.

Some public attitudes challenge effective fuel management. While prescribed burning is widely promoted by various agencies, and in the media, grazing is not. Grazing for commercial livestock production is an extensive land use that has low energy requirements and relies mostly on rainfall-based forage on lands unsuitable for crop production. Grazing has significant biodiversity benefits through removing non-native, habitat-choking biomass (Huntsinger and Oviedo, 2014), and produces unprocessed, high quality, food. The public often does not recognize how much of California's landscape is grazed because grazing is extensive and livestock may not be often be visually present. They often do not make the connection with much appreciated wildflower blooms facilitated by removal of exotic biomass. When they encounter cattle on public lands people may be intimidated by their size and unfamiliar with cattle behaviors (Barry, 2014). Negative and often exaggerated media claims about the contribution of cattle to climate change and environmental degradation raises questions about why cattle are allowed to graze, especially on public open space lands meant to preserve nature. Yet all of agriculture, including livestock production and its attendant activities, emits around $8 \%$ of California greenhouse emissions, while transportation emits 41\% (California Air Resources Board, 2021). Emissions from rangeland grazing are mostly in the form of short-lived gases that do not accumulate over long periods rather than carbon dioxide that persists and accumulates for hundreds of years in the atmosphere, and the land conserved through ranch ownership is a carbon sink.

Grazing seems harder for professional forestry and land management agencies to accept as a fuel reduction tool. For the forestry and fire agencies, who, especially when it comes to fire, operate largely under a command and control model, ranching and ranchers are a diverse group not generally subject to agency regulations. In a culture of uniforms, regulation, and careful control, grazing is managed by all sorts of people with all sorts of goals, at all kinds of scales and on private lands, without permits from a regulatory agency, lacking a set of common and licensed plans and practices. While forest landowners must get a permit from CalFire and several other agencies to sell timber, rangeland landowners are not required to get agency approval to sell livestock into the production chain. The somewhat chaotic characteristics of the ranching industry, and the high value placed on individual autonomy, seem likely to be challenging to a command and control agency. This has also limited prescribed burning.

The current discussion of foodscapes and sustainable food production offers an opportunity to work toward changing some attitudes, and ideally, marketing could be linked to creating sustainable and fire-resistant ecosystems. Grazing around the WUI can reduce flammable fuels and create productive, or working fuelbreaks (Figure 13). If you talk to fire-fighters on the ground, grazed areas make valuable staging areas for fire-fighting (Huntsinger, pers. com.). Agencies should widely promote grazing in outreach material about wildfire. CalFire and the Forest Service have, after all, responsibilities for rangelands as well as forests.

In addition to more information about the effectiveness of deliberate grazing for fire control, knowledge of what ecosystems, regions, and vegetation types are amenable to different treatments, including grazing, is essential for practitioners. As with any treatment, knowing the very local vegetation conditions and dynamics is needed (Fernandes and Botelho, 2003). A statewide database of what is known about best practices for using fire and grazing in different parts of the state should be part of the developing effort to reduce catastrophic fire. Existing databases, 
in particular the Ecological Site Descriptions of the United States Department of Agriculture Natural Resources Conservation Service (NRCS) should incorporate fire hazard reduction goals. Ecological Site Descriptions should be finished for California. The state and transition models used are ideal for incorporating and organizing data-driven vegetation management information and results from research and other verified sources. Incentives could provide compensation to commercial grazers if biomass removal has to go beyond what is best for production. Management innovations and incentives for purposeful grazing to reduce fuels are likely still to result in less expensive control than with prescribed burning and many other treatments, and the need for planning and management is no more and maybe less onerous. Integrated planning using fire, thinning, and grazing offers the potential for long lasting effectiveness.

Learning from and working with Natural Resources Conservation Service and University of California Extension personnel with expertise in grazing management and experience working with livestock producers could be a step forward. In fact, there is an unfortunate gap between forestry and rangeland management as professions, yet the vegetation does not recognize this gap, intermixing and sharing resources across the landscape. Livestock grazing, prescribed and cultural burning, and thinning and clearing are essential tools as California faces climate change and landscape fragmentation.

\section{REFERENCES}

Abatzoglou, J. T., and Williams, A. P. (2016). Impact of anthropogenic climate change on wildfire across western US forests. Proc. Natl. Acad. Sci. U.S.A. 113, 11770-11775. doi: 10.1073/pnas.1607171113

Aguilera, R., Corringham, T., Gershunov, A., and Benmarhnia, T. (2021). Wildfire smoke impacts respiratory health more than fine particles from other sources: observational evidence from Southern California. Nat. Commun. 12:1493. doi: 10.1038/s41467-021-21708-0

Allen, E. B., McDonald, C., and Hilbig, B. E. (2019). Long-Term Prospects for Restoration of Coastal Sage Scrub: Invasive Species, Nitrogen Deposition, and Novel Ecosystems. General Technical Report -Pacific Southwest Research Station, USDA Forest Service GTR-PSW-26, 1-18.

Anderson, M. K. (2013). Tending the Wild: Native American Knowledge and the Management of California's Natural Resources. Berkeley, CA: University of California Press.

Archibald, S., Lehmann, C. A. R., Gomez-Dans, J. S., and Bradstock, R. A. (2013). Defining pyromes and global syndromes of fire regimes. Proc. Natl. Acad. Sci. U.S.A. 110, 6442-6447. doi: 10.1073/pnas.1211466110

Archibald, S., Staver, A. C., and Levin, S. A. (2012). Evolution of humandriven fire regimes in Africa. Proc. Natl. Acad. Sci. U.S.A. 109, 847-852. doi: 10.1073/pnas.1118648109

Axelson, J. N., Battles, J., Bulaon, B. M., and Cluck, D. (2019). The California Tree Mortality Data Collection Network - enhanced communications and collaboration among scientists and stakeholders. Calif. Agr. 73, 55-62. doi: $10.3733 /$ ca.2019a0001

Barnhart, S. J., McBride, J. R., and Warner, P. (1996). Invasion of northern oak woodlands by Pseudotsuga menziesii (Mirb.) Franco in the Sonoma Mountains of California. Madroño 28-45.

Barro, S. C., and Conard, S. G. (1991). Fire effects on California chaparral systems: an overview. Env. Int. 17, 135-149. doi: 10.1016/0160-4120(91)900 96-9

Barry, S. (2021). Livestock mobility through integrated beef production-scapes supports rangeland livestock production and conservation. Front. Sust. Food Syst. 4:269. doi: 10.3389/fsufs.2020.549359
Each have a significant part to play as we work to restore fire resistant landscapes. People in general don't like to see familiar landscapes change (Waks et al., 2019), but regardless, our forest and rangeland landscapes are already changing. The question we have to answer is, do we want to give ourselves choices about how future places look and what they provide, or let it be decided for us?.

\section{AUTHOR CONTRIBUTIONS}

LH wrote the draft manuscript. SB contributed writing and ideas and edited it. Both authors contributed to the article and approved the submitted version.

\section{ACKNOWLEDGMENTS}

The authors wish to thank Matthew Shapero for sharing his knowledge of grazing and brushlands with us. We thank Jiarui Wang and CeeCee Chen for help with the literature review. Thank you to Suzanne Vetter, Dave Daley, and Paul Starrs for their very helpful reviews. We acknowledge funding from the University of California Berkeley, the University of California, Division of Agriculture and Natural Resources, and from the National Institute of Food and Agriculture, McIntire-Stennis CA-B-ECO-0239-MS.
Barry, S., and Huntsinger, L. (2021). Rangeland land-sharing, livestock grazing's role in the conservation of imperiled species. Sustainability 13:4466. doi: $10.3390 /$ su13084466

Barry, S. J. (2014). Using social media to discover public values, interests, and perceptions about cattle grazing on park lands. Environ. Manage. 53, 454-464. doi: 10.1007/s00267-013-0216-4

Barton, G. A. (2000). Empire forestry and American environmentalism. Environ. Hist. 6, 187-203. doi: 10.3197/0967340001293 42271

Bassein, J., Ganesh, S., Pena-Ponce, M. D., De Backer, J., Lanclus, M., Belmans, D., et al. (2019). Wildfire smoke exposure during infancy results in impaired lung function. Eur. Resp. J. 54:PA2830. doi: 10.1183/13993003.congress-2019.PA2830

Becchetti, T., George, M., McDougald, N., Dudley, D., Connor, M., Vaughn, C., et al. (2016) Annual Range Forage Production. ANR publication 8018. Available online at: https://anrcatalog.ucanr.edu/pdf/8018.pdf (accessed August 5, 2021).

Behan, R. W. (1975). Forestry and the end of innocence. Am. For. 81, 16-19.

Biswell, H. H., Taber, R. D., Hedrick, D. W., and Schultz, A. M. (1952). Management of chamise brushlands for game in the north coast region of California. Calif. Fish Game 38, 471-475.

Blackburn, T. C., and Anderson, K. (1993). Before The Wilderness: Environmental Management by Native Californians. Santa Barbara, CA: Ballena Press.

Bowers, E. A., Fernow, B. E., Olmstead, F. L., Rothrock, J. F., Colvin, V., Roosevelt, T., et al. (1895). Comments on professor Charles S. Sargent's scheme of forest preservation by military control. Century Magaz. 49, 626-634.

Bowman, D. M. J. S., Balch, J. K., Artaxo, P., Bond, W. J., Carlson, J. M., Cochrane, M. A., et al. (2009). Fire in the earth system. Science 324, 481-484. doi: $10.1126 /$ science. 1163886

Bradbury, D. E. (1978). The evolution and persistence of a local sage/chamise community pattern in southern California. Yearbook Assoc. Pac. Coast Geog. 40, 39-56. doi: 10.1353/pcg.1978.0012

Bugalho, M. N., Caldeira, M. C., Pereira, J. S., Aronson, J., and Pausas, J. G. (2011). Mediterranean cork oak savannas require human use to sustain biodiversity and ecosystem services. Front. Ecol. and Envron. 9, 278-286. doi: $10.1890 / 100084$ 
Burcham, L. T. (1982). California Range Land: An Historico-Ecological Study of the Range Resource of California. Davis, CA: University of California.

Burke, M. (2020). G-FEED: Indirect Mortality From Recent Wildfires in CA. Available online at: http://www.g-feed.com/2020/09/indirect-mortality-fromrecent.html (accessed May 19, 2021).

Burnett, P. H. (1852). "Governor's annual message to the legislature, January 7 , 1851," in Journals of the Senate and Assembly of the State of California, at the Second Session of the Legislature, 1851-1852 (San Francisco, CA: G. K. Fitch \& Co., and V. E. Geiger \& Co., State Printers), 15.

California Air Resources Board (2020). Public Comment Draft: Greenhouse Gas Emissions of Contemporary Wildfire, Prescribed Fire, and Forest Management Activities. Available online at: https://aboutblaw.com/UU1 (accessed May 19, 2021).

California Air Resources Board (2021). Current California GHG Emission Inventory Data. Available online at: https://ww2.arb.ca.gov/ghg-inventory-data (accessed May 19, 2021).

California Cattlemen's Association (2021). Cattle Grazing Is Key to Mitigating California Wildfires. Available online at: https://calcattlemen.org/portfolioitems/wildfire/ (accessed July 17, 2021).

California Department of Forestry and Fire Protection (2010). California Forests and Rangelands: 2010 Assessment. Sacramento, CA: Fire and Forest Resources Assessment Program.

Cochrane, M. A., and Laurance, W. F. (2008). Synergisms among fire, land use, and climate change in the Amazon. AMBIO 37, 522-527. doi: 10.1579/0044-7447-37.7.522

Colantoni, A., Egidi, G., Quaranta, G., D’Alessandro, R., Vinci, S., Turco, R., et al. (2020). Sustainable land management, wildfire risk and the role of grazing in Mediterranean urban-rural interfaces: a regional approach from Greece. Land 9:21. doi: $10.3390 /$ land 9010021

Collins, R. D., de Neufville, R., Claro, J., Oliveira, T., and Pacheco, A. P. (2013). Forest fire management to avoid unintended consequences: a case study of Portugal using system dynamics. J. Environ. Manage. 130, 1-9. doi: 10.1016/j.jenvman.2013.08.033

Comptroller of the State of California (1859). Expenditures for Military Expeditions Against Indians, 1851-1859. Secretary of State, Sacramento, California State Archives, Comptroller No. 574, Vault, Bin 393.

Conlisk, E., Swab, R., Martínez-Berdeja, A., and Daugherty, M. P. (2016). Post-fire recovery in coastal sage scrub: seed rain and community trajectory. PLoS ONE 11:e0162777. doi: 10.1371/journal.pone.0162777

Cook, S. F. (1976). The Population of the California Indians, 1769 -1970. Berkeley, CA: University of California Press.

Cronon, W. (1983). Changes in the Land: Indians, Colonists, and the Ecology of New England. New York, NY: Hill and Wang.

Daley, D. (2021). Cattle Grazing and Prescribed Burns Can Help California Beat Devastating Wildfires. Sacramento Bee. Available online at: https:// www.sacbee.com/opinion/op-ed/article248955889.html (accessed May 19, 2021).

Damianidis, C., Santiago-Freijanes, J. J., den Herder, M., Burgess, P. J., Mosquera Losada, M. R., Graves, A., et al. (2020). Agroforestry as a sustainable land use option to reduce wildfires risk in European Mediterranean areas. Agroforest. Syst. 95, 919-929. doi: 10.1007/s10457-020-00 482-w

Davies, K. W., Bates, J. D., Svejcar, T. J., and Boyd, C. S. (2010). Effects of long-term livestock grazing on fuel characteristics in rangelands: an example from the sagebrush steppe. Rangel. Ecol. Manag. 63, 662-669. doi: 10.2111/REM-D-10-00006.1

Davies, K. W., Boyd, C. S., Bates, J. D., and Hulet, A. (2015). Dormant season grazing may decrease wildfire probability by increasing fuel moisture and reducing fuel amount and continuity. Int. J. Wildl. Fire 24, 849-856. doi: 10.1071/WF14209

Davies, K. W., and Nafus, A. M. (2013). Exotic annual grass invasion alters fuel amounts, continuity and moisture content. Int. J. Wildl. Fire 22, 353-358. doi: 10.1071/WF11161

Davis, K. T., Dobrowski, S. Z., Higuera, P. E., Holden, Z. A., Veblen, T. T., Rother, M. T., et al. (2019). Wildfires and climate change push low-elevation forests across a critical climate threshold for tree regeneration. Proc. Natl. Acad. Sci. U.S.A. 116, 6193-6198. doi: 10.1073/pnas.1815107116
DeBuys, W. (2001). Salt Dreams: Land and Water in Low-Down California. New Mexico Hist. Rev. 76. Available online at: https://www.digitalrepository.unm. edu/nmhr/vol76/iss $2 / 5$

Dechter, L. (2021, May 16). Shasta-trinity national forest lightning complex consists of 10 fires. Action News. Available online at: https://www. actionnewsnow.com/content/news/Shasta-Trinity-National-Forest-LighningComplex-574432951.html (accessed July 17, 2021).

DeFlorio-Barker, S., Crooks, J., Reyes, J., and Rappold, A. G. (2019). Cardiopulmonary effects of fine particulate matter exposure among older adults, during wildfire and non-wildfire periods, in the United States 2008-2010. Environ. Health Perspect. 127:37006. doi: 10.1289/EHP3860

Diaz, J. M. (2012). Economic Impacts of Wildfire. Southern Fire Exchange. Fact Sheet 2012-7. Available online at https://fireadaptednetwork.org/wp-content/ uploads/2014/03/economic_costs_of_wildfires.pdf (accessed August 6, 2021).

Dudley, W. R. (1896). Forest reservations: with a report on the Sierra reservation, California. Sierra Club Bull. 1, 254-267.

East Bay Regional Parks (2021). Grazing. Available online at: https://www.ebparks. org/about/stewardship/grazing/ (accessed July 17, 2021).

Evett, R. R., and Cuthrell, R. Q. (2013). Phytolith evidence for a grass-dominated prairie landscape at Quiroste Valley on the central coast of California. Calif. Archael. 5, 319-335. doi: 10.1179/1947461X13Z.00000000017

Fadadu, R. P., Grimes, B., Jewell, N. P., Vargo, J., Young, A. T., Abuabara, K., et al. (2021). Association of wildfire air pollution and health care use for atopic dermatitis and itch. JAMA Dermatol. 157, 658-666. doi: 10.1001/jamadermatol.2021.0179

Fairfax, S. K., and Fortmann, L. (1990). American forestry professionalism in the Third World: some preliminary observations. Popul. Environ. 11, 259-272. doi: 10.1007/BF01256459

Fargione, J., Hill, J., Tilman, D., Polasky, S., and Hawthorne, P. (2008). Land clearing and the biofuel carbon debt. Science 319, 1235-1238. doi: $10.1126 /$ science. 1152747

Fernandes, P. M., Barros, A. M. G., Pinto, A., and Santos, J. A. (2016). Characteristics and controls of extremely large wildfires in the western Mediterranean Basin. J. Geophys. Res. Biogeosciences 121, 2141-2157. doi: 10.1002/2016JG003389

Fernandes, P. M., and Botelho, H. S. (2003). A review of prescribed burning effectiveness in fire hazard reduction. Int. J. Wildl. Fire 12, 117-128. doi: 10.1071/WF02042

Ferranto, S., Huntsinger, L., Getz, C., Nakamura, G., Stewart, W., Drill, S., et al. (2011). Forest and rangeland owners value land for natural amenities and as financial investment. Calif. Agric. 65, 184-191. doi: 10.3733/ca.v065n04p184

Flagg, J. M. (1934-1943). Your Forests-Your Fault-Your Loss. Washington, DC: Oil on canvas, Smithsonian American Art Museum, United States Forest Service.

Forest Management Task Force (2021). California's Wildfire and Forest Resilience Action Plan. Available online at: https://www.fire.ca.gov/media/ps4p2vck/ californiawildfireandforestresilienceactionplan.pdf (accessed May 19, 2021).

Fried, J. S., and Huntsinger, L. (1998). Managing for naturalness at Mt. Diablo state park. Soc. Nat. Resour. 11, 505-516. doi: 10.1080/08941929809381097

Germano, D. J., Rathbun, G. B., and Saslaw, L. R. (2011). Effects of grazing and invasive grasses on desert vertebrates in California. J. Wildl. Manage. 76, 670-682. doi: 10.1002/jwmg.316

Global Fire Data (2021). Global Fire Emissions Database. Available online at: https://www.globalfiredata.org (accessed May 19, 2021).

Godsey, S. E., Kirchner, J. W., and Tague, C. L. (2013). Effects of changes in winter snowpacks on summer low flows: case studies in the Sierra Nevada, California, USA. Hydrol. Process. 28, 5048-5064. doi: 10.1002/hyp.9943

Gómez-Ibañez, D. A. (1977). Energy, economics, and the decline of transhumance, Geogr. Rev. 67, 284-298. doi: 10.2307/213723

Goulden, M. L., and Bales, R. C. (2019). California forest die-off linked to multiyear deep soil drying 2012-2015. Nat. Geosci. 12, 632-637.

Green, L. R., Hughes, C. L., and Graves, W. L. (1979). Goat control of brush regrowth on southern California fuelbreaks. Rangelands Archives 1, 117-119.

Hagerty, C. (2020, October 19). Prescribed Burn Associations are one answer to California's megafires: community groups seek to fill in the gap left by overtaxed agencies. Sierra Magazine. Available online at: https://www.sierraclub.org/ sierra/prescribed-burn-associations-are-one-answer-california-s-megafires (accessed May 25, 2021) 
Haikerwal, A., Akram, M., Del Monaco, A., Smith, K., Sim, M. R., Meyer, M., et al. (2015). Impact of fine particulate matter (PM 2.5) exposure during wildfires on cardiovascular health outcomes. J. Am. Heart Assoc. 4:e001653. doi: 10.1161/JAHA.114.001653

Harris, J. A., Hobbs, R. J., Higgs, E., and Aronson, J. (2006). Ecological restoration and global climate change. Restor. Ecol. 14, 170-176. doi: 10.1111/j.1526-100X.2006.00136.x

Hastings, M. S., Barnhart, S., and McBride, J. R. (1996). Restoration Management of Northern Oak Woodlands. USDA Forest Service General Technical Reports PSW-GTR-160, 275-280.

Heady, H. F., and Zinke, P. J. (1978). Vegetational Changes in Yosemite Valley. Washington, DC: U. S. Department of the Interior.

Heizer, R. F. (ed.). (1972). George Gibbs' Journal of Redick McKee's Expedition in Northwestern California, 1851. Berkeley, CA: Archeological Research Facility, University of California. Available online at: http://georgegibbsandjamesswan. blogspot.com/2014/02/george-gibbs-journal-of-redick-mckees.html (accessed August 6, 2021).

Hobbs, R. J., Higgs, E., Hall, C. M., Bridgewater, P., Chapin, F. S., Ellis, E. C., et al. (2014). Managing the whole landscape: historical, hybrid, and novel ecosystems. Front. Ecol. Environ. 12, 557-564. doi: 10.1890/130300

Huntsinger, L. (1997). Use of livestock grazing to manage understory vegetation in a California silvo-pastoral system: effects of season, intensity, and frequency of grazing. Agroforest. Syst. 34, 67-82. doi: 10.1007/BF00129633

Huntsinger, L. (2016). "The tragedy of the common narrative: Re-telling degradation in the American West," in The end of Desertification? Disputing Environmental Change in the Drylands, eds R. H. Behnke and M. Mortimore (Berlin; Heidelberg: Springer), 293-323. doi: 10.1007/978-3-642-16014-1_11

Huntsinger, L., and Bartolome, J. W. (2014). Cows? In California? Rangelands and livestock in the Golden State. Rangelands 36, 4-10. doi: 10.2111/Rangelands-D-14-00019.1

Huntsinger, L., Forero, L. C., and Sulak, A. (2010). Transhumance and pastoralist resilience in the western United States. Pastor. Res. Policy, Pract. 1, 1-15. doi: 10.3362/2041-7136.2010.002

Huntsinger, L., and McCaffrey, S. (1995). A forest for the trees: forest management and the Yurok environment, 1850 to 1994. Am. Indian Cult. Res. J. 19, 155-192. doi: 10.17953/aicr.19.4.cv0758kh373323h1

Huntsinger, L., and Oviedo, J. (2014). Ecosystem services may be better termed social ecological services in a traditional pastoral system: the case of California Mediterranean rangelands at multiple scales. Ecol. Soc. 19:8. doi: 10.5751/ES-06143-190108

Ingram, R. S., Doran, M. P., and Nader, G. (2013). "Planned herbivory in the management of wildland fuels," in Herbivory, eds B. Barros and E. B. Fernandes (InTech Open Ebook: eBook (PDF)).

Jackson, L. E. (1985). Ecological origins of California's Mediterranean grasses. J. Biogeogr. 12, 349-361. doi: 10.2307/2844866

Joffre, R., Rambal, S., and Ratte, J. P. (1999). The dehesa system of southern Spain and Portugal as a natural ecosystem mimic. Agroforest. Syst. 45, 57-79. doi: 10.1023/A:1006259402496

Johnston, F. H., Henderson, S. B., Chen, Y., Randerson, J. T., Marlier, M., DeFries, R. S., et al. (2012). Estimated global mortality attributable to smoke from landscape fires. Environ. Health Perspect. 120, 695-701. doi: $10.1289 /$ ehp. 1104422

Keele, D. M., and Malmsheimer, R. W. (2018). Time spent in Federal Court: US Forest Service Land Management Litigation 1989-2008. Forest Sci. 64, 170-190.

Keeley, J. E. (2002). Native American impacts on fire regimes of the California coastal ranges. J. Biogeogr. 29, 303-320. doi: 10.1046/j.1365-2699.2002.00676.x

Keeley, J. E., Lubin, D., and Fotheringham, C. J. (2003). Fire and grazing impacts on plant diversity and alien plant invasions in the southern Sierra Nevada. Ecol. Appl. 13, 1355-1374. doi: 10.1890/02-5002

Keeley, J. E., and Syphard, A. D. (2019). Twenty-first century California, USA, wildfires: fuel-dominated vs. wind-dominated fires. Fire Ecol. 15:24. doi: 10.1186/s42408-019-0041-0

Kocher, S. D., and Butsic, V. (2017). Governance of land use planning to reduce fire risk to homes Mediterranean France and California. Land 6:24. doi: 10.3390/land6020024

Koman, P. D., Billmire, M., Baker, K. R., De Majo, R., Anderson, F. J., Hoshiko, S., et al. (2019). Mapping modeled exposure of wildland fire smoke for human health studies in California. Atmosphere 10:308. doi: 10.3390/atmos10060308
Kosco, B. H., and Bartolome, J. W. (1983). Effects of cattle and deer on regenerating mixed conifer clearcuts. J. Range Manage. 36, 265-268. doi: 10.2307/3898178

Kousky, C., Greig, K., Lingle, B., and Kunreuther, H. (2018). Wildfire Cost in California: The Role of Electric Utilities. Issue Brief. Philadelphia, PA: Wharton University Risk Management and Decision Processes Center, August. Available online at: https://riskcenter.wharton.upenn.edu/wp-content/uploads/2018/08/ Wildfire-Cost-in-CA-Role-of-Utilities-1.pdf (accessed August 6, 2021).

Kramer, H. A., Mockrin, M. H., Alexandre, P. M., and Radeloff, V. C. (2019). High wildfire damage in interface communities in California. Int. J. Wildl. Fire 28, 641-650. doi: 10.1071/WF18108

Lake, F. K. (2021). Indigenous fire stewardship: Federal/Tribal partnerships for wildland fire research and management. Fire Manag. Today 79, 30-39. Available online at: https://www.fs.fed.us/psw/publications/lake/psw_2021_lake001.pdf (accessed August 6, 2021).

Langmann, B., Duncan, B., Textor, C., Trentmann, J., and van der Werf, G. R. (2009). Vegetation fire emissions and their impact on air pollution and climate. Atmos. Environ. 43, 107-116. doi: 10.1016/j.atmosenv.2008.09.047

Larvie, K., Moody, T., Axelson, J., Fettig, C., and Cafferata, P. (2019). Synthesis of Research into the Long-Term Outlook for Sierra Nevada Forests following the Current Bark Beetle Epidemic. California Forestry Note No. 122, California Department of Forestry and Fire Protection. Available online at: https://www. fs.fed.us/psw/publications/fettig/psw_2019_fettig003_larvie.pdf (accessed May 19, 2021).

Lasaux, M., and Kocher, S. D. (2006). Fuel Reduction Guide for Sierra Nevada Forest Landowners. University of California Cooperative Extension. University of California Cooperative Extension, Central Sierra No. 88262. Available online at: http://cecentralsierra.ucanr.edu/files/88262.pdf (accessed May 25, 2021).

Launchbaugh, K., Brammer, B., Brooks, M. L., Bunting, S., Clark, P., Davison, J., et al. (2008). Interactions Among Livestock Grazing, Vegetation Type, and Fire Behavior in the Murphy Wildland Fire Complex in Idaho and Nevada, July 2007. US Geological Survey Open-File Report 1214, 42. doi: 10.3133/ofr20081214

Legislative Analyst's Office (2018). Improving California's Forest and Watershed Management. Sacto, CA: Legislative Analyst's Office. Available online at: https:// lao.ca.gov/Publications/Report/3798 (accessed May 25, 2021).

Leiberg, J. B. (1902). Forest Conditions in the Northern Sierra Nevada, California. Washington, DC: US Government Printing Office. doi: 10.3133/pp8

Liang, Y., Jen, C. N., Weber, R. J., Misztal, P. K., and Goldstein, A. H. (2021). Chemical composition of PM 2.5 in October 2017 Northern California wildfire plumes. Atmos. Chem. Phys. 21, 5719-5737. doi: 10.5194/acp-21-57 19-2021

Lightfoot, K. G., and Cuthrell, R. Q. (2015). Anthropogenic burning and the Anthropocene in late-Holocene California. Holocene 25, 1581-1587. doi: $10.1177 / 0959683615588376$

Loud, L. L. (1918). Ethnogeography and Archaeology of the Wiyot Territory, University of California publications. Am. Archaeol. Ethnol. 14, 221-423.

Lovreglio, R., Meddour-Sahar, O., and Leone, V. (2014). Goat grazing as a wildfire prevention tool, a basic review. iForest 7, 260-268. doi: 10.3832/ifor11 12-007

Lubetkin, K. C., Westerling, A. L., and Kueppers, L. M. (2017). Climate and landscape drive the pace and pattern of conifer encroachment into subalpine meadows. Ecol. Appl. 27, 1876-1887. doi: 10.1002/eap. 1574

Macon, D. (2014). The art and science of targeted grazing-a producer's perspective. Rangelands 36, 31-35. doi: 10.2111/Rangelands-D-14-00028.1

Marks-Block, T., Lake, F. K., Bird, R. B., and Curran, L. M. (2021). Revitalized Karuk and Yurok cultural burning to enhance California hazelnut for basketweaving in northwestern California, USA. Fire Ecol. 17:6. doi: 10.1186/s42408-021-00092-6

McBride, J., and Heady, H. F. (1968). Invasion of grassland by Baccharis pilularis DC. J. Range Manage. 21, 106-108. doi: 10.2307/3896366

McBride, J. R. (1974). Plant succession in the Berkeley Hills, California. Madroño 22, 317-329.

McBride, J. R., and Kent, J. (2019). The failure of planning to address the urban interface and intermix fire-hazard problems in the San Francisco Bay Area. Int. J. Wildl. Fire 28, 515-517. doi: 10.1071/WF18107

McKelvey, K. S., and Weatherspoon, C. P. (1992). Projected Trends in Owl Habitat, Chapter 13. USDA Forest Service General Technical Reports PSWGTR-133, 261-273. 
Merriam, K. E., Keeley, J. E., and Beyers, J. L. (2006). Fuel breaks affect nonnative species abundance in Californian plant communities. Ecol. Appl. 16, 515-517. doi: 10.1890/1051-0761(2006)016[0515:FBANSA]2.0.CO;2

Miller, C. (2001). Gifford Pinchot and the Making of Modern Environmentalism. Boulder, CO: Island Press.

Miller, R. K., Field, C. B., and Mach, K. J. (2020). Barriers and enablers for prescribed burns for wildfire management in California. Nat. Sust. 3, 101-109. doi: 10.1038/s41893-019-0451-7

Minnich, R. A., and Franco-Vizcaíno, E. (2003). "Divergence in Californian vegetation and fire regimes induced by differences in fire management across the US-Mexico boundary," in Both Sides of the Border, eds J. J. Batema, L. Fernandez, R. T. Carson (Dordrecht: Springer), 385-402. doi: 10.1007/0-306-47961-3_18

Moore, D., Copes, R., Fisk, R., Joy, R., Chan, K., and Brauer, M. (2006). Population health effects of air quality changes due to forest fires in British Columbia in 2003. Can. J. Public Heal. 97, 105-108. doi: 10.1007/BF03405325

Moreira, F., Ascoli, D., Safford, H., Adams, M. A., Moreno, J. M., Pereira, J. M. C., et al. (2020). Wildfire management in Mediterranean-type regions: paradigm change needed. Environ. Res. Lett. 15:011001. doi: 10.1088/1748-9326/ab541e

Moreno, J. M., and Oechel, W. C. (1991). Fire intensity and herbivory effects on postfire resprouting of Adenostoma fasciculatum in southern California chaparral. Oecologia 85, 429-433 doi: 10.1007/BF00320621

Morrow, J. O. (1918). Letter to Pete Hufford, Whitmore, CA; Red Bluff, CA: Forest Supervisor's Office, United States Forest Service, Shasta-Trinity National Forest, April 12. Hufford Family Archives.

Muir, J. (1911). My First Summer in the Sierra. Boston, MA: Houghton Mifflin. doi: 10.5962/bhl.title.19229

Muir, J. (1979). John of the Mountains: The Unpublished Journals of John Muir. Madison, WI: University of Wisconsin Press.

Nader, N., Henkin, Z., Smith, E., Ingram, R., and Narvaez, N. (2007). Planned herbivory in the management of wildfire fuels. Rangelands 29, 18-24. doi: 10.2111/1551-501X(2007)29[18:PHITMO]2.0.CO;2

Naeher, L. P., Brauer, M., Lipsett, M., Zelikoff, J. T., Simpson, C. D., Koenig, J. Q., et al. (2007). Woodsmoke health effects: a review. Inhal. Toxicol. 19, 67-106. doi: 10.1080/08958370600985875

Narvaez, N., Brosh, A., Mellado, M., and Pittroff, W. (2011). Potential contribution of Quercus durata and Adenostoma fasciculatum supplemented with Medicago sativa on intake and digestibility in sheep and goats. Agroforest Syst. 83, 279-286. doi: 10.1007/s10457-011-9387-2

National Interagency Fire Center (2021). Statistics: National Report of Wildland Fires and Acres Burned by State. Available online at: https:// www.predictiveservices.nifc.gov/intelligence/2020_statssumm/fires_acres20. pdf (accessed May 25, 2021).

National Oceanic and Atmospheric Administration (2021). California Average Temperature January-December. Annual Time Series. Available online at: https://www.ncdc.noaa.gov/cag/statewide/time-series/4/tavg/ann/4/19002021 ?base_prd=trueandbegbaseyear $=1901$ andendbaseyear $=2000 \quad$ (accessed May 25, 2021).

Naudts, K., Chen, Y., McGrath, M. J., Ryder, J., Valade, A., Otto, J., et al. (2016). Europe's forest management did not mitigate climate warming. Science 351, 597-600. doi: 10.1126/science.aad7270

New York Times (1918). Nation's Heads Ask Fire Prevention; President Wilson Sends Message Deploring Destruction of Resources in Wartime. Available online at: http://query.nytimes.com/gst/abstract.html?res= 9A0CE4DF1239E13ABC4B53DFB7678383609EDE [accessed May 19, 2021].

North, M. P., and Hurteau, M. D. (2011). High-severity wildfire effects on carbon stocks and emissions in fuels treated and untreated forest. Forest Ecol. Manage. 261, 1115-1120.

Nunamaker, C., De Lasaux, M., and Nakamura, G. (2007). Wildfire and Fuels Management. University of California Division of Agricultural and Natural Resources Forest Stewardship Series 15, Publication 8245. Available online at: https://anrcatalog.ucanr.edu/pdf/8245.pdf (accessed August 5, 2021).

Oles, K. M., Weixelman, D. A., Lile, D. F., Tate, K. W., Snell, L. K., and Roche, L. M. (2017). Riparian meadow response to modern conservation grazing management. Environ. Manage. 60, 383-395. doi: 10.1007/s00267-0170897-1

Ortega, M., Saura, S., Gonzalez-Avila, S., Gomez-Sanz, V., and Elena-Rossello, R. (2012). Landscape vulnerability to wildfires at the forest-agriculture interface: half-century patterns in Spain assessed through the SISPARES monitoring framework. Agroforest Syst. 85, 331-349 doi: 10.1007/s10457-011-9 423-2

Paphitis, N., and Gatopoulos, D. (2019, March 7). Greece: poor response, planning blamed for wildfire deaths. AP News. Available online at: https://apnews.com/ article/ab131a3124ff4fd4a5d8ce55e7ba8371 (accessed May 25, 2021).

Pathak, T. B., Maskey, M. L., Dahlberg, J. A., Kearns, F., Bali, K. M., and Zaccaria, D. (2018). Climate change trends and impacts on California agriculture: a detailed review. Agronomy 8:25. doi: 10.3390/agronomy8030025

Pausas, J. G., and Fernández-Muñoz, S. (2011). Fire regime changes in the Western Mediterranean Basin: from fuel-limited to drought-driven fire regime. Clim. Change 110, 215-226. doi: 10.1007/s10584-011-0060-6

Polis, C. (2014, March 7). Drought and historical rainfall in California. Bytemuse. com. Available online at: http://bytemuse.com/post/drought-historicalrainfall-california/ (accessed August 5, 2021).

Powell, J. W. (1890). "PART VI - advice for the century," in Seeing Things Whole: the Essential John Wesley Powell, ed W. DeBuys (Washington, DC: Island Press), 289.

Powers, S. (1872). The Northern California Indians. Overland Monthly and Out West Magazine 9, 305-313. Available online at: http://name.umdl.umich.edu/ ahj1472.1-09.004 (accessed May 19, 2021).

Prunicki, M., Cauwenberghs, N., Lee, J., Zhou, X., Movassagh, H., Noth, E., et al. (2021). Air pollution exposure is linked with methylation of immunoregulatory genes, altered immune cell profiles, and increased blood pressure in children. Sci. Rep. 11:4067. doi: 10.1038/s41598-02183577-3

Pyne, S. J. (1997). Fire in America: A Cultural History of Wildland and Rural Fire. Seattle, WA: University of Washington Press.

Quinn-Davison, L., and Stackhouse, J. (2019). Burning by the Day: Why Cost/Acre Is Not a Good Metric for Prescribed Fire. Grasslands Summer, 16-19.

Radeloff, V. C., Helmers, D. P., Kramer, H. A., Mockrin, M. H., Alexandre, P. M., Bar-Massada, A., et al. (2018). Rapid growth of the US wildland-urban interface raises wildfire risk. Proc. Natl. Acad. Sci. U.S.A. 115, 3314-3319. doi: 10.1073/pnas. 1718850115

Rao, D. (2020). Benefits of Cattle Grazing for Reducing Fire Fuels and Fire Hazard. University of California Division of Agricultural and Natural Resources, Livestock and Range Blog. Available online at: https://ucanr.edu/blogs/ blogcore/postdetail.cfm?postnum $=43533$ (accessed August 6, 2021).

Reid, C. E., Brauer, M., Johnston, F. H., Jerrett, M., Balmes, J. R., and Elliott, C. T. (2016). Critical review of health impacts of wildfire smoke exposure. Environ. Health Perspect. 124, 1334-1343. doi: 10.1289/ehp.1409277

Richards, L., Brew, N., and Smith, L. (2020). 2019-20 Australian BushfiresFrequently Asked Questions: A Quick Guide-Parliament of Australia. Available online at: https://www.aph.gov.au/About_Parliament/Parliamentary_ Departments/Parliamentary_Library/pubs/rp/rp1920/Quick_Guides/ AustralianBushfires (accessed May 19, 2021).

Russell, W. H., and McBride, J. R. (2003). Landscape scale vegetation-type conversion and fire hazard in the San Francisco Bay Area open spaces. Landsc. Urb. Plann. 64, 201-208. doi: 10.1016/S0169-2046(02)00233-5

Safford, H. D., and Van de Water, K. M. (2014). Using Fire Return Interval Departure (FRID) Analysis to Map Spatial and Temporal Changes in Fire Frequency on National Forest Lands in California. Pacific Southwest Research Station, USDA Forest Service PSW-RP-266, 59. doi: 10.2737/PSW-RP-266

Saitua, I. (2019). "Flagging the Lines": Basque immigrant sheepherders and the early US Forest Administration in Nevada, 1890-1920. Hist. Agrar. 77, 137-168. doi: 10.26882/histagrar.077e06s

Sampson, A.W., and Jespersen, B.S. (1963). California Range Brushlands and Browse Plants. Oakland, CA: University of California Division of Agriculture and Natural Resources. Available online at: https://ucanr.edu/sites/UCCE_LR/ files/180508.pdf (accessed August 6, 2021).

Sayre, N. F. (2018). "Race, nature, nation, and property in the origins of range science," in The Palgrave Handbook of Critical Physical Geography, eds R. Lave, C. Biermann, and S. Lane (New York, NY: Palgrave Macmillan), 339-356. doi: 10.1007/978-3-319-71461-5_16

Schama, S. (1995). Landscape and Memory. Toronto, CA: Vintage Canada.

Seastedt, T. R., Hobbs, R. J., and Suding, K. N. (2008). Management of novel ecosystems: are novel approaches required? Front. Ecol. Environ. 6, 547-553 doi: $10.1890 / 070046$ 
Sidahmed, A., Morris, J., Radosevich, S., and Graves, W.L. (1978). Assessment of goat grazing in chaparral. Calif. Agricul. 32, 12-13.

Sidahmed, A., Radosevich, S., Morris, J., and Koong, L. (1982). Nutritive value of chaparral for goats grazing in fuel-breaks. Calif. Agricul. 36, 12-14.

Sikkink, P. G., Lutes, D. C., and Keane, R. E. (2009). Field guide for identifying fuel loading models. General Technical Reports RMRS-GTR-225. doi: 10.2737/RMRS-GTR-225

Skinner, C. N., and Chang, C. (1996). Fire Regimes, Past and Present, in Sierra Nevada Ecosystem Project: Final Report to Congress, Vol. 2. Assessments and Scientific Basis for Management Options. Wildland Resources Center Report No. 37. Centers for Water and Wildland Resources, University of California, Davis (U. S. Forest Service), 1041-1069.

Sommer, L. (2020). To Manage Wildfire, California Looks to What Tribes Have Known All Along. NPR, Hear Every Voice. Available online at: https://www. npr.org/2020/08/24/899422710/to-manage-wildfire-california-looks-towhat-tribes-have-known-all-along (accessed July 17, 2021).

Spiegal, S., Huntsinger, L., Hopkinson, P., and Bartolome, J. W. (2016). “ Chapter 37. Range ecosystems," in Ecosystems of California, eds H. Mooney and E. Zavaleta (Berkeley, CA: University of California Press), 835-864.

Starrs, C. F., Butsic, V., Stephens, C., and Stewart, W. (2018). The impact of land ownership, firefighting, and reserve status on fire probability in California. Environ. Res. Lett. 13:034025. doi: 10.1088/1748-9326/aaaad1

Stewart, J. A., E., van Mantgem, P. J., Young, D. J. N., Shive, K. L., Preisler, H. K., Das, A. J., et al. (2020). Effects of postfire climate and seed availability on postfire conifer regeneration. Ecol. Appl. 31:e02280. doi: 10.1002/eap.2280

Sudworth, G.B, and Gannett, H. (1900). Stanislaus and Lake Tahoe Forest Reserves, California, and Adjacent Territory. Washington, DC: Twenty-first annual report of the USGS, Part V, Forest Reserves. U. S. Government Printing Office.

Syifa, M., Panahi, M., and Lee, C. W. (2020). Mapping of post-wildfire burned area using a hybrid algorithm and satellite data: the case of the Camp Fire wildfire in California, USA. Remote Sens. 12:623. doi: 10.3390/rs12040623

Tarrega, R., Calvo, L., Taboada, A., Garcia-Tejero, S., and Marcos, E. (2009). Abandonment and management in Spanish dehesa systems: effects on soil features and plant species richness and composition. For. Ecol. Manage. 257, 731-738. doi: 10.1016/j.foreco.2008.10.004

Taylor, A. H. (1990). Tree invasion in meadows of Lassen Volcanic National Park, California. Profess. Geogr. 43, 457-470. doi: 10.1111/j.0033-0124.1990.00457.x

Taylor, A. H. (1995). Forest Expansion and Climate Change in the Mountain Hemlock (Tsuga mertensiana) Zone, Lassen Volcanic National Park, California, U.S.A. Artic Alpine Res. 27, 206-216. doi: 10.2307/15 51951

Tosca, M. G., Randerson, J. T., Zender, C. S., Flanner, M. G., and Rasch, P. J. (2010). Do biomass burning aerosols intensify drought in equatorial Asia during El Niño? Atmos. Chem. Phys. 10, 3515-3528. doi: 10.5194/acp-10-3515-2010

Turco, M., Jerez, S., Augusto, S., Tarín-Carrasco, P., Ratola, N., Jiménez-Guerrero, P., et al. (2019). Climate drivers of the 2017 devastating fires in Portugal. Sci. Rep. 9:13886. doi: 10.1038/s41598-019-50281-2

United States Department of Agriculture, Forest Service (2005). A Strategic Assessment of Forest Biomass and Fuel Reduction Treatments in Western States. General Technical Reports RMRS-GTR-149.

United States Department of Agriculture, Forest Service (2021). Fire Effects Database. Available online at: https://www.feis-crs.org/feis/ (accessed August 6, 2021).

United States Forest Service and State of California (2020). MOU Agreement for Shared Stewardship of California's Forest and Rangelands between the State of California and the USDA, Forest Service Pacific Southwest Region, August 12. Available online at: https://www.gov.ca.gov/wp-content/uploads/2020/08/8.12. 20-CA-Shared-Stewardship-MOU.pdf (accessed August 6, 2021).

University of California Cooperative Extension (1) (2021). Reducing Forest Fuels: Grazing. Available online at: https://ucanr.edu/sites/fire/Prepare/Treatment/ Grazing/ (accessed July 4, 2021).

University of California Cooperative Extension (2) (2021). Grazing for Fire Prevention. Livestock and Natural Resources Information Center - Plumas, Sierra and Butte Counties. Available online at: https://ucanr.edu/sites/ Rangelands/Grazing_for_Fire_Prevention_/ (accessed July 4, 2021).

University of California CooperativeExtension, California Invasive Plant Council, Environmental Protection Agency (2021). Methods for Managing Weeds in Wildlands: Non-Chemical Control. WeedCut Tool. Available online at: https://weedcut.ipm.ucanr.edu/management-practices/grazing/\#gsc.tab=0 (accessed July 17, 2021).

van der Werf, G. R., Randerson, J. T., Giglio, L., Collatz, G. J., Mu, M., Kasibhatla, P. S., et al. (2010). Global fire emissions and the contribution of deforestation, savanna, forest, agricultural, and peat fires (1997-2009). Atmos. Chem. Phys. 10, 11707-11735. doi: 10.5194/acp-10-11707-2010

Vetter, S. (2005). Rangelands at equilibrium and non-equilibrium: Recent developments in the debate. J. Arid Envron. 62, 321-341.

Waks, L., Kocher, S., and Huntsinger, L. (2019). Landowner perspectives on reforestation following a high-severity wildfire in California. J. For. 117, 30-37. doi: 10.1093/jofore/fvy071

Wang, D., Guan, D., Zhu, S., MacKinnon, M., Geng, G., Zhang, Q., et al. (2021). Economic footprint of California wildfires in 2018. Nat. Sustain. 4, 252-260. doi: 10.1038/s41893-020-00646-7

Weatherspoon, C. P., and Skinner, C. N. (1996). "Landscape-level strategies for forest fuel management," in Sierra Nevada Ecosystems, in Final Report to Congress, Vol. 2. Assessments and Scientific Basis for Management Options. Wildland Resources Center Report No. 37. Centers for Water and Wildland Resources, University of California, Davis (U. S. Forest Service), 1471-1492.

Weill, A. (2018). Fuel Matters: Why Wildfire Behavior Depends on What's Burning. KQED. Available online at: https://www.kqed.org/science/1928625/_trashed35 (accessed May 19, 2021).

Westerling, A. L., and Bryant, B. P. (2007). Climate change and wildfire in California. Clim. Change 87, 231-249. doi: 10.1007/s10584-007-9363-z

Wettstein, Z. S., Hoshiko, S., Fahimi, J., Harrison, R. J., Cascio, W. E., and Rappold, A. G. (2018). Cardiovascular and cerebrovascular emergency department visits associated with wildfire smoke exposure in California in 2015. J. Am. Heart Assoc. 7:e007492. doi: 10.1161/JAHA.117.007492

Wood, S. (2020). Lack of Grazing, Prescribed Burns Adds Fuel to California's Wildfires, Say Experts and Stakeholders. The North Bay Business Journal. Available online at: https://www.northbaybusinessjournal.com/article/ industrynews/lack-of-grazing-prescribed-burns-adds-fuel-to-californiaswildfires-say/ (accessed May 19, 2021).

Yokelson, R. J., Karl, T., Artaxo, P., Blake, D. R., Christian, T. J., Griffith, D. W. T., et al. (2007). The Tropical Forest and Fire Emissions Experiment: overview and airborne fire emission factor measurements. Atmos. Chem. Phys. 7, 5175-5196. doi: 10.5194/acp-7-5175-2007

Yoon, J., Kravitz, B., and Rasch, P. (2015). Extreme fire season in California: a glimpse into the future? Bull. Am. Meteorol. Soc. 96, S5-S9. doi: 10.1175/BAMS-D-15-00114.1

Young, D. J. N., Werner, C. M., Welch, K. R., Young, T. P., Safford, H. D., and Latimer, A. M. (2019). Post-fire forest regeneration shows limited climate tracking and potential for drought-induced type conversion. Ecology 100:e02571. doi: 10.1002/ecy.2571

Yu, P. F., Toon, O. B., Bardeen, C. G., Zhu, Y. Q., Rosenlof, K. H., Portmann, R. W., et al. (2019). Black carbon lofts wildfire smoke high into the stratosphere to form a persistent plume. Science 365, 587-590. doi: 10.1126/science.aax1748

Zhang, X., Chen, X., and Zhang, X. (2018). The impact of exposure to air pollution on cognitive performance. Proc. Natl. Acad. Sci. U.S.A. 115, 9193-9197. doi: $10.1073 /$ pnas. 1809474115

Conflict of Interest: The authors declare that the research was conducted in the absence of any commercial or financial relationships that could be construed as a potential conflict of interest.

Publisher's Note: All claims expressed in this article are solely those of the authors and do not necessarily represent those of their affiliated organizations, or those of the publisher, the editors and the reviewers. Any product that may be evaluated in this article, or claim that may be made by its manufacturer, is not guaranteed or endorsed by the publisher.

Copyright (C) 2021 Huntsinger and Barry. This is an open-access article distributed under the terms of the Creative Commons Attribution License (CC BY). The use, distribution or reproduction in other forums is permitted, provided the original author(s) and the copyright owner(s) are credited and that the original publication in this journal is cited, in accordance with accepted academic practice. No use, distribution or reproduction is permitted which does not comply with these terms. 